\title{
Reflections on the Use of Social Networking Sites as an Interactive Tool for Data Dissemination in Digital Archaeology
}

\author{
Dominik Hagmann ${ }^{\mathrm{a}^{*}}$ \\ ${ }^{a}$ Department of Classical Archaeology, Faculty of Historical and Cultural Studies, University of Vienna, Franz-Klein-Gasse 1, 1190 Vienna, Austria
}

\section{ARTICLE INFO}

Article history:

Received: $2^{\text {nd }}$ January 2018

Accepted: $4^{\text {th }}$ April 2018

DOI: http://dx.doi.org/ 10.24916/iansa.2018.1.1

\section{Key words:}

digital archaeology

public archaeology

information and communication technologies

social media

Twitter

Sketchfab

ResearchGate

open access

science communication

data dissemination

\begin{abstract}
A BSTRACT
Based on a case study, the paper analyses the possibilities of social media as a tool for science communication in the context of information and communication technology (ICT) usage in archaeology. Aside from discussing the characteristics of digital archaeology, the social networking sites (SNS) Twitter, Sketchfab, and ResearchGate are integrated into a digital research data dissemination tool. As a result, above-average engagement rates with few impressions were observed. Compared with that, status updates focusing on actual fieldwork and other research activities gain high numbers of impressions with below-average engagement rates. It is believed that most of the interactions are restricted to a core audience and that a clearly defined social media strategy is obligatory for successful research data dissemination in archaeology, combined with regular posts in the SNS. Additionally, active followers are of highest importance.
\end{abstract}

\section{Introduction}

This paper presents a case study concerning the use of the social networking sites (SNS) Twitter, Sketchfab, and ResearchGate as an integrated tool for digital science communication in archaeology. Although this combination seems to be characterised by means of a distinct heterogeneity among the different SNS, the interlocking of the various sites will be highlighted and its importance outlined. Therefore, the basic workflow for combining a microblogging service with a $3 \mathrm{D}$ content sharing site and a scientific social network shall be delineated within the framework of science communication.

Disseminating data digitally can be handled in different ways, both actively and passively. An active manner can be the triggering of a social media war: in general, war might be seen here as permanent adversity between at least two parties. This adversity can arise for various reasons and take

*Corresponding author. E-mail: dominik.hagmann@univie.ac.at different courses on different intensity levels (Kekes 2010). Expanding the meaning of war to include digital conflicts within the realm of information and computer science, this permanent adversity can be easily combined with social media, specifically the social web, as an integral part of Web 2.0 (e.g. Conole, Dyke, 2016; Ebersbach et al., 2016, pp. 1133; Neal, 2012; Rheingold, 1993; O’Reilly, 2005; Stephens, 2007; Zuppo, 2012). Accordingly, war may have various definitions within social media: Firstly, a social media war may mean a public disagreement on a certain question which is outrageously debated using social media (e.g. Woolston, 2015). Secondly, and more indirectly, a social media war may also describe a fight between two or more opposing social media services themselves (e.g. Ganahl, 2013). Thirdly, the complex and quite well-known case of using social media as a toolset for history, memory, propaganda or even as a weapon - in the manner of symmetric and asymmetric warfare - has to be considered too (e.g. Comunello, Anzera, 2012; Jones, Baines, 2013; van Niekerk, Maharaj, 2013; Farwell, 2014; Klausen, 2014; Lawson, 2014; Lähteenmäki, Virta, 2016; 
Patrikarakos, 2017). Social media wars also occur in the free web-based social messaging and microblogging service Twitter, which is used to send short posts (so-called tweets) with originally 140 characters and (since November 2017) 280 characters in some countries (e.g. Rosen, 2017; Richardson, 2012; 2015; Williams, Krause, 2012, pp. 105-113).

Originally, it is likely that Twitter wars (in their broadest sense) have become a digital phenomenon in the context of the Israeli-Palestinian conflict, and thus became known to a wider public during 2012 (Ball, 2013), considering the role of social media in modern warfare (Sutter, 2012). Hence Twitter war initially belongs to the above-mentioned third definition, incorporating the metaphysical meanings of real and virtual war, but may have adopted additional meanings besides. Thus, a Twitter war may also belong to the first type of social media war. In today's Twitter lingo (slang) a Twitter war may describe in detail a quick public dialogue based on tweets between at least two parties for several hours. The parties involved are addressing each other mainly using the so-called retweet- $(R T)$ as well as replies- (Replying to) and mentions-functions (@) on Twitter (Twitter, 2017a; 2017b).

A quick review of last months' tweets mentioning the combined terms "Twitter" and "war" reveals the characteristics of a Twitter war in general (Twitter, 2017d). Twitter wars seem to be declared by either one of the two parties or even a third party without following any formal rules. Through simply announcing an explicit statement as well as directly mentioning the other party/parties, the Twitter war starts. Here, one party refers to a certain position while the other party/parties take/s an opposite one. The other party/parties respond/s to this statement with a similar but differing statement more or less immediately. Afterwards, the first party responds again, etc. Other recipients of the dialogue within this Twitter war can comment on individual tweets and may therefore be addressed by the opponents afterwards. This special type of discussion may be conducted as friendly banter but also as a serious debate, depending on the parties involved.

Regarding the rhetoric of Twitter users, \#twitterwar as well as \#TwitterWar, \#Twitterwar, and \#TWITTERWAR are used, although the term may be also used without any hashtag (e.g. Kehrberg, 2015; Twitter, 2017d). A hashtag thereby serves as a freely definable visual emphasis of the particular word, as well as a linking tag inside the service that enables users to filter the millions of different messages based on a selected keyword by just clicking on it or searching for it (e.g. Bruns et al., 2016; Enli, Simonsen, 2017; Small, 2011; Twitter, 2017c).

The main reason to start a Twitter war may be to stimulate public attention on a large scale. Furthermore, a Twitter war is a social media marketing strategy which gains the attention of customers for all parties involved. It is important that only equal competitors start a Twitter war and that the involved parties treat each other with respect during the whole confrontation (Alaimo, 2017). Otherwise a Twitter war could quickly become something else, like a case of internet "trolling", i.e. the attempt to provoke the counterpart and to outrage him/her, or even flaming (e.g. Kohn, 2015). Additionally, Twitter itself sometimes encourages such activities (e.g.@TwitterNotify, 2017). Users may further formerly invite or provoke each other to start a Twitter war through using a matching hashtag in a corresponding post, although this kind of request usually would not have the desired effect.

An example of a Twitter war is the "conflict" between Denmark and Sweden in 2016: On July $7^{\text {th }}$, a Twitter war broke out between the Danish Foreign Ministry and the Swedish Institute and lasted for several hours (@denmarkdotdk, 2017; @swendense, 2017). It all started when the Danish Foreign Ministry quoted a post from the Swedish Institute about special aspects of Swedish taste in interior decoration, which primarily was meant for the amusement of the Swedish Twitter community (@denmarkdotdk, 2016b; Podhovnik, 2016; @swendense, 2016b). The Swedes responded to that tweet, then the Danes countered and the whole conversation culminated into an alternating struggle for amusement (@denmarkdotdk,2016a; @swendense, 2016c). As the Swedish Institute stated during the discussion repetitively, the whole conversation was meant as "friendly rivalry" (@swendense, 2016a).

All in all, a Twitter war may be one concept (among others) of gaining attention of a vast group of interested users as a first step to sell one's product to this target group. It is a specialised marketing strategy which uses digital information and communication technology (ICT) to gain success in getting noticed. ICT is more important than ever nowadays, mainly due to the high availability of the internet in many parts of the world, although a serious digital divide still exists (Cancro, 2016; Mano, 2012, pp. 30-31; Walker, 2014). Nevertheless, ICT has a very serious impact on society, and thus the effect of ICT on archaeology can also be observed (e.g. Henson, 2013).

The strategy presented here may be settled in a more passive setting and Twitter wars are hard to find in the field of archaeology. Maybe the archaeological Twitter community is too small and homogenous, or "big players" within this community are not big enough for occurrences like Twitter wars to appear regularly in archaeology. Considering the wider field of cultural heritage management, a recent example from digital museology may be the Twitter war of two British museums in 2017: On September 13 ${ }^{\text {th }}$, in the course of the \#AskACurator-campaign by Mar Dixon, another Twitter war occurred between the Science Museum and Natural History Museum in Great Britain, because of the question posed by Twitter user Bednarz O'Connell regarding which museum would have the best exhibition (@bednarz, 2017a, 2017b; Dixon, 2013). While this Twitter war was actually started by an individual non-museologist, there are concepts which try to facilitate mutual as well as pluralistic activities on Twitter in archaeology, like the first CAA Twitter Conference (\#CAATCO 2018). Furthermore, it is questionable whether an active and possibly even aggressive marketing concept like that conducted during a Twitter war is suitable for archaeology. 
This paper seeks to evaluate the role of SNS regarding their function as platforms for science communication in the context of digital archaeology (e.g. Kansa et al., 2012; Watkins, 2016). In contrast to a Twitter war, the general concept presented here is, in a sense, passive, because although information is actively disseminated, it must also be received by other Twitter users who are not actively involved. A Twitter war, however, is active in all aspects, as not only information is disseminated, but other users are also actively involved. Founded on the evaluation of a case study, it is examined whether it is necessary to start a Twitter war to successfully disseminate information in archaeology. To do so, recent Twitter data received from an official university's account will be analysed.

\section{Digital archaeology}

Digital archaeology itself is an integral part of today's archaeological practice and a broad area encompassing various aspects, methods, and ideas (e.g. Hagmann, 2017a; 2017b; 2017f; Langendorf et al., 2017; Morgan, Eve, 2012; Trognitz et al., 2017). However, digital archaeology seems to be neither an archaeological sub-discipline nor its own specialisation, but rather a pool of different theoretical and practical aspects of information technology and their corresponding applications within archaeology (Costopoulos, 2016; Huggett, 2017). Applying digital methods in archaeology expands the possibilities of creating insights and generating knowledge (Zubrow, 2006). In this sense, Zubrow (2006) defines digital archaeology as the usage of "[...] future technology to understand past behaviour [...]". Therefore, theory and practice of combined digital input, digital information management, digital analysis, and digital publication are immanent for digital archaeology.

In regard to the above, Daly and Evans (2006) mention in their fundamental compilation about digital archaeology that this field of study "[...] explores the basic relationships that archaeologists have with Information and Communication Technology [...]" - a situation, which may be also found in the digital humanities (e.g. Jannidis et al., 2017). The relationship between archaeology and ICT, as well as the term digital archaeology itself, have different names, such as archaeological informatics (Archäoinformatik in some German-speaking countries), cyber archaeology, virtual archaeology, and so on (e.g. Djindjian, 2015; Hookk, 2016; Levy, 2014; Reilly, 1990). There are no clear-cut borders and, according to Grosman (2016), one can state that the varying nomenclature is due to "many groups of scientists worldwide, [which] almost concurrently recognized the immense power of computer technology". Additional digital neighbouring "disciplines" also exist, such as the highly independent, do-it-yourself and mainly self-funded punk archaeology, as well as digital geoarchaeology, digital history, digital literary history, digital musicology, or digital philology (e.g. Ghilardi, Desruelles, 2009; Graham et al., 2016; Gregory, 2014; Murrieta-Flores et al., 2017; Nichols,
Altschul, 2012; Pugin, 2015; Richardson, 2017; Schofield, 2017; Siart et al., 2017).

Depending on one's personal definition of archaeology, digital archaeology may be defined - at least in a taxonomic view - as an integral part of the digital humanities (e.g. Burdick, 2012; Warwick et al., 2012). However, it seems difficult to treat digital archaeology and digital humanities as equivalent (e.g. Reiche et al., 2014): considering the research history of both fields, it seems that there are only a few points of interaction between digital humanities and digital archaeology. Indeed, digital archaeology may have evolved nearly on its own (Thaller, 2017b; Zubrow, 2006, pp. 12-21). At most, these two fields have only merged recently through individual projects which offer a few zones of overlap (e.g. dha, 2017; Kaplan, 2015). Actually, digital humanities mainly seem to encompass varying methods of digital text analysis in the broadest sense, the development and usage of various database applications, open access, studies in metadata, image classification research, as well as long term data archiving (e.g. Bair, Carlson, 2008; Berry, 2012; DHd, 2018 Köln, 2017; Diao, Hernández, 2014; Funkhouser et al., 2011; Manovich, 2012; Röhle, 2012; Thaller, 2017a). In this case, one should question if incorporating digital archaeology into digital humanities would not solely be a matter of taxonomy, regarding their highly diverse characteristics and the role of interdisciplinarity in archaeology (e.g. CAA International, 2017; Hirst, 2008). However, if one defines archaeology as a social science instead of assigning it to the humanities or cultural studies, these interconnections may be completely altered again (Smith et al., 2012).

Comparing digital archaeology and digital geoarchaeology may show that these different digital "disciplines" are more formally divided than they practically are. Recently, it was claimed that the use of digital methods and applications derived from geomatics in an archaeological context would define digital geoarchaeology (Siart et al., 2017). Nonetheless, spatial analysis using geographic information systems (GIS), for example, is inherent to archaeology, geology, geomatics, geoarchaeology, digital geoarchaeology, as well as digital archaeology (e.g. Djindjian, 1998; Schörner, Hagmann, 2015; Verhagen, 2017; Zubrow, 2006, pp. 16-21). In other words, it should be considered if it is even possible to make a precise distinction between a geoarchaeologist and a digital archaeologist while they are doing fieldwork and using GIS. So, it seems that such a definition might be valid only if rigid boundaries are defined between these different fields - a state that is quite atypical for archaeology (e.g. Sinclair, 2016). Moreover, the number of disciplines using even the same digital methods and tools is not limited to digital geoarchaeology and digital archaeology. For example, digital dissemination strategies such as open access publishing, repositories, wikis, blogs, photo and video platforms are of highest importance for digital archaeology as well as for nearly all other scientific disciplines nowadays (Bauer et al., 2015; Morgan, 2015; Richardson, 2017; Xia, 2012). Furthermore, the question is if an autonomous discipline arises because of the usage 
of digital methods. One must consider if topics like ICT in archaeology and the neighbouring branches require their own digital archaeological disciplines and sub-disciplines, or whether one should think of something else, especially considering previously neglected aspects (Huggett, 2015a; 2015b).

Consequently, ICT seems to be situated in between all disciplines. So, digital archaeology as the theory and practice of the complex use of ICT throughout archaeology may be positioned more likely on a meta-level than being its own specialisation or discipline. The same can be assumed for digital zooarchaeology, digital Judaic studies, digital classics, etc. (e.g. Betts et al., 2011; Campbell, 2015; Schubert, 2015). One might therefore suggest that sophisticated digital practice based on ICT within a given specialisation creates the corresponding digital meta-discipline.

\section{Research data dissemination}

As mentioned above, social media have an important role in today's society and in archaeology (e.g. Gennaro, 2015; Richardson, 2014; Rocks-Macqueen, 2016; Sedlacik, 2015; Laracuente, 2016; Wolf, 2017). Twitter, especially, can be regarded as an influential SNS, serving as a platform for individual messaging as well as for elaborate science communication. Innovative projects like the Public Archaeology Twitter Conference show the high potential of this service for science communication (\#PATC 2017).

Different kinds of social media, such as microblogging services like Twitter, and research networks like Academia.edu, can be integrated for more effective outreach, for example to enhance public reception of a newly published research paper (e.g. Shuai et al., 2012; Thelwall, Kousha, 2014). Going one step further, the combination of the various abilities of social media can create a holistic digital scientific communication tool. Thus, it is a question of the integration of different kinds of social media to form an interactive tool for archaeological research data dissemination - with all its innovations, advantages, disadvantages and problems (e.g. Perry, Beale, 2015; Huvila, 2013). Research data may be defined here as every kind of digital information available in archaeology, including digital objects like texts, tables, and photos, as well as ready-made publications such as research papers and monographies (Brin et al., 2013). Such a digital archaeological communication tool is settled at a point of disciplinary intersection and strongly overlaps with public archaeology "[...] viewed through the lens of the internet" (Lake, 2012, p. 476). So, the role this tool plays in digital research data dissemination should also be considered (e.g. Denning, 2004; Miles, 2004). The tool may be used online, (mainly) without restriction world-wide, interactively, and may be comprised of numerous forms of social media, such as online wikis, blogs, photo as well as video platforms, and social networks (e.g. Scholz, 2017). Because of its bidirectional nature, the tool allows enhanced use and reuse of data made available on open access and other online repositories and the sustainable publication of the metadata via the internet, enabling a public digital discourse and evaluation of the data (Kansa et al., 2014; Niyazov et al., 2016). Through these means, the idea of open science or, more precisely, open archaeology, can be realised (Lake, 2012; Morgan, Eve, 2012; Zhu, Purdam, 2017).

Due to the heterogenous characteristics of social media, the SNS used should be chosen precisely: for example, Instagram, a (primarily) mobile application, mainly focuses on photos, videos, and GIFs and is mostly used as a sophisticated marketing tool for individuals as well as for organisations in various fields (e.g. Firsching, 2017; Moon et al., 2016; Sheldon, Bryant, 2016). Controversially, however, this SNS is even used for e-commerce and trafficking of cultural heritage, including human remains (Huffer, Graham, 2017). Apart from this, Instagram is not perfectly suitable for archaeological research data dissemination. For instance, there is currently only the possibility of adding non-clickable hyperlinks in combination with a single post. Without using paid features or additional applications, clickable hyperlinks are available on one's so-called bio (i.e. personal account description) only (Kobilke, 2016).

Twitter is arguably a more important tool for information dissemination and communication. Posts are received very directly and can reach wide audiences and gain numerous interactions within a very short time. Not surprisingly, Twitter is also extensively used in several scientific disciplines aside from archaeology. Here, Twitter is mainly used for information dissemination, but also serves as a data source for different types of Big Data analysis (e.g. Cavanillas et al., 2016). Disciplines like economics, medicine, educational research, or architecture, as well as professionals like journalists, are using Twitter and its data, based on the interactions of hundreds of thousands of users and millions of data-sets to examine numerous kinds of research questions. Examples include optimised customer service conversations, the behaviour of people with traumatic brain injuries, or urban land-use (e.g. Ahmad, 2010; Evans, 2014; Oraby et al., 2017; Soliman et al., 2017; Vobič et al., 2016; Workewych et al., 2017).

\section{Methodology}

Twitter is a suitable tool for specialised research data dissemination, using hyperlinks, one of the most essential components of the internet (Berners-Lee et al., 1994; BernersLee, 1997). One of these workflows is described through a basic example here: a 3D model of trench 2/2014 from the Roman excavation at Molino San Vincenzo in Tuscany/ Italy was uploaded to the 3D content sharing platform Sketchfab (Hagmann et al., 2015; Lloyd, 2016; Sketchfab, 2017). The model, hosted on this platform, was embedded in a tweet: one can view the embedded model interactively within the tweet or follow the reference to Sketchfab (@) rrl_univie, 2017c; Hagmann, Reiter, 2016c). Additional information is provided there too and offers further content 
through linking to other webpages, for example, the overallproject website, Google Maps, the website of the excavation project itself, or the author's personal homepage (Dominik Hagmann, 2017; Google Maps, 2017; Molino San Vincenzo, 2017; Roman Rural Landscapes, 2017). Importantly, the data of the $3 \mathrm{D}$ model is provided on ResearchGate as a data repository and linked to the model (Hagmann, Reiter, 2016a; 2016b; Kowalczyk, 2014; Thelwall, Kousha, 2015). The data can be retrieved as 3D geometries (COLLADA) and textures (JPEG) and all files are citable through digital object identifiers (DOIs; Agisoft PhotoScan, 2017; COLLADA, 2017; JPEG, 2017; DOI, 2017). ResearchGate is used in this special case as a repository mainly because of the high level of awareness of this platform within the scientific community and the possibility of assigning DOIs to digital resources. Long-term data archiving will be performed using the institutional repository Phaidra of the University of Vienna, and it is easy to link the digital objects on ResearchGate and Phaidra (Borrego, 2017; Jeffrey, 2012; Nicholas et al., 2016; Solodovnik, Budroni, 2015; Thelwall, Kousha, 2017; Yu et al., 2016). The mentioned websites have a (mostly) barrier-free, responsive web design and there are mobile applications for devices like smartphones and tablets available (e.g. Bernacki et al., 2016; Kerkmann, Lewandowski, 2015). These technical specifications also help to dissolve the digital divide, at least partially.

At the Department of Classical Archaeology at the University of Vienna, selected (scientific) social media platforms are used for digital public outreach. Twitter serves as an official channel for various forms of science communication pertaining to the research activities of a newly established and specialised cluster of projects called Roman Rural Landscapes (RRL). These projects mainly focus on settlements in the Mediterranean and Central European countryside during ancient times (e.g. Banks et al., 2017; Gabellone, 2015; Pinfield et al., 2014; PapmehlDufay, Söderström, 2017; Richardson, Dixon, 2017; RocksMacqueen, 2016; Williams, Atkin, 2015; Zuanni, 2017).

Within this framework, Twitter activities started on May $15^{\text {th }}, 2017$, operated by the author. On December $22^{\text {nd }}, 2017$, the account had a quite small audience of 165 followers. The data-set analysed below is formed by the contents and metrics of all tweets $(n=46)$ from June $1^{\text {st }}$ to September $22^{\text {nd }}, 2017$, retrieved from Twitter Analytics between July $31^{\text {st }}$ and November 10 ${ }^{\text {th }}, 2017$ (Hagmann, 2017c; Twitter Analytics, 2017). The account had 145 followers during this time (averaged due to slight fluctuations). The tweets mainly contained various status updates with associated scientific background. 21 tweets within this period were themed to the excavation project Molino San Vincenzo and thus represent the majority of the posts (Hagmann et al., 2015). Therefore, two additional data-sets (obtained from Twitter Analytics on September $9^{\text {th }}$ and October $12^{\text {th }}, 2017$ ), representing the subset of the excavation-related tweets described above, containing all tweets $(n=23)$ from the period August $2^{\text {nd }}$ to August $30^{\text {th }}, 2017$ are also analysed (Hagmann, 2017d, 2017e). Descriptive analysis was performed on selected qualitative and quantitative aspects of these Twitter metrics (e.g. Bol, 2010): aside from the published content of the tweet as text, general technical details like the unique identification number of the tweet or the permanent URI are among them. Further aspects, like the timestamp or the number of times how often embedded media (photos, videos, GIFs, embedded models etc.) within the tweet were shared with other Twitter users were regarded too. Attention was paid to the number of times the tweet was shown to a Twitter user (i.e. impressions), as well as the interactions (i.e. engagements), and the engagement rate (i.e. the impressions divided by the engagements). For their part, the engagements are composed of various kinds of special actions, like retweets, replies, likes, profile clicks, link clicks, hashtag clicks, detail expands, and media interactions (Twitter, 2017e). No paid Twitter Ads campaigns for increasing the performances of the tweets through promotion were used - only so-called organic activities are considered (@buster, 2014; Twitter, 2017f). Aside from simple calculations, the standard deviation (std. dev.) as well as the arithmetic mean and median were calculated using MS Excel (Excel, 2017a; 2017b; 2017c). MS Excel and Adobe Illustrator were used for the visualisation of the data and for generating the charts (Adobe, 2017; Microsoft, 2017). The datasets are licensed under a CC BY 4.0 International License (Creative Commons, 2017).

\section{Results}

During the period of 114 days, 46 tweets were posted, which means 1 tweet per c. 2.5 days on average (Figure 1): 11 tweets were posted in June, 7 tweets in July, 25 tweets in August and 3 tweets from September $1^{\text {st }}$ to $22^{\text {nd }}, 2017$. The tweets have 609.2 (std. dev. 1140.8) impressions on average, with a minimum of 75 and a maximum of 5497 impressions per tweet. The average number of engagements is 12.1 (std. dev. 14.1) with a minimum of 1 and a maximum of 82 (Figure 2). The average engagement rate is 0.03 (std. dev. 0.01 ), or $3 \%$, with a minimum value of $0.004(0.4 \%)$ and a maximum value of 0.08 , respectively $8 \%$ (Figure 3 ). The median engagement rate is 0.03 (3\%) (Hagmann, 2017c).

Comparable values can be observed for the subset of tweets ( $\mathrm{n}=23$ ) from August 2017, which were received from Twitter Analytics on September 4 $4^{\text {th }}, 2017$ (Figure 4): per tweet, 784.7 (std. dev. 1349.9) impressions are recorded, with a minimum of 105 and a maximum of 5497 shares. On average, the tweets have 16.0 (std. dev. 18.1) engagements (minimum: 2, maximum: 82) and a mean engagement rate of 0.03 (std. dev. 0.01), also 3\%. The minimum average engagement rate is $0.004(0.4 \%)$, the median engagement rate is $0.03(3 \%)$, the maximum average engagement ratevalue is $0.08(8 \%)$ (Hagmann, 2017d).

Regarding impressions and engagements, the most successful tweet, no. 892754365618028544 , was published on August $2^{\text {nd }}, 2017$. It is an informal status update mentioning the preparations for the 2017 season at Molino San Vincenzo in Tuscany. The message gained 5497 impressions and 


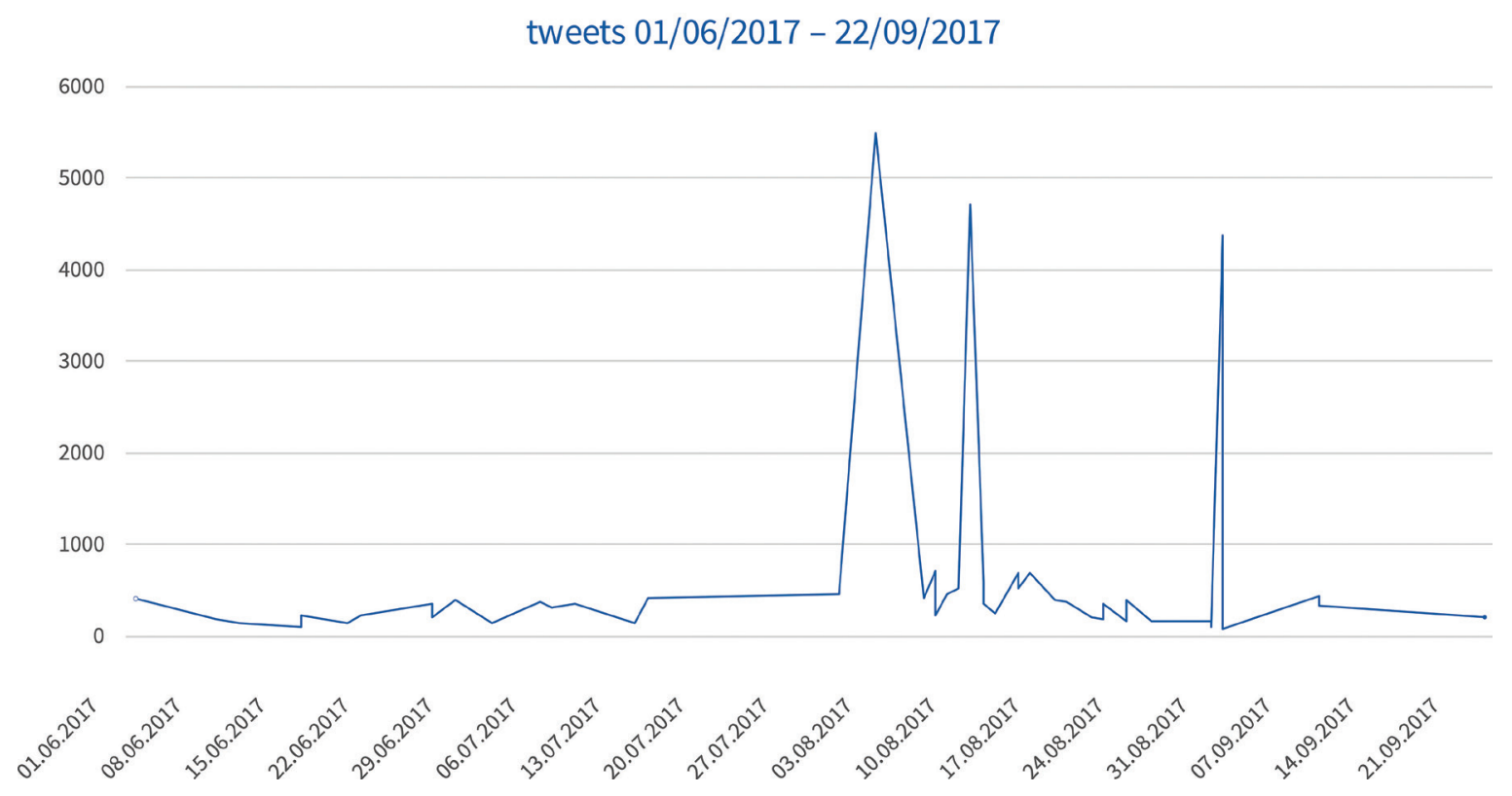

Figure 1. Impressions of the tweets $(n=46)$ from 2017-06-01 to 2017-09-22 (Dominik Hagmann, 2017. Data received from Twitter Analytics).

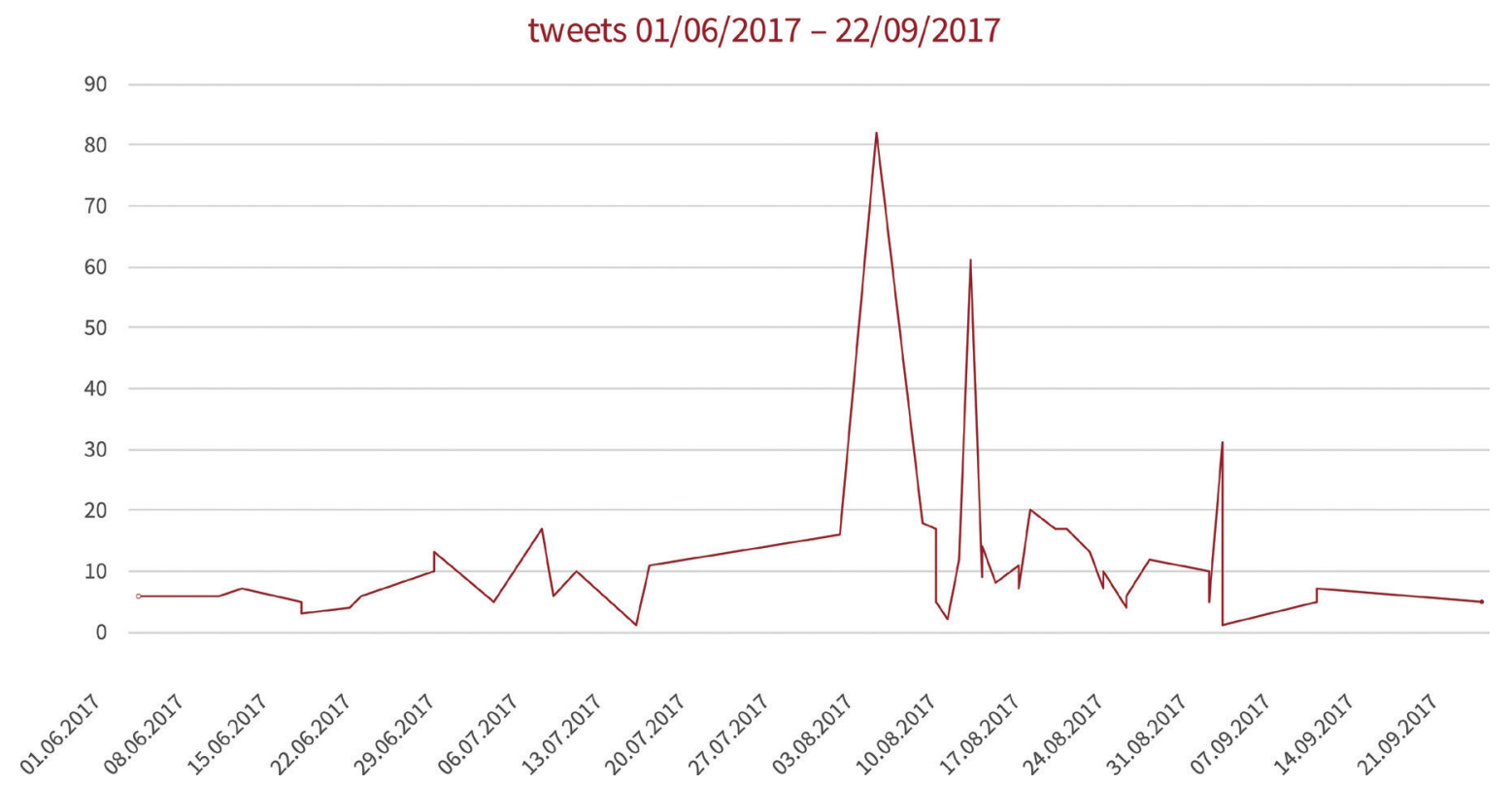

Figure 2. Engagements of the tweets (n=46) from 2017-06-01 to 2017-09-22 (Dominik Hagmann, 2017. Data received from Twitter Analytics).

82 engagements (@rrl_univie, 2017a). The least successful tweet, no. 902917404883394560 , is from August $30^{\text {th }}, 2017$. It gained 105 impressions and 5 engagements, and relates to the publishing of a 3D model according to the data dissemination workflow mentioned above (@rrl_univie 2017b). With regard to engagement rate, however, the reverse conclusion can be drawn: tweet no. 902917404883394560 achieved a better rate of c. 5\% than tweet 892754365618028544 (c. 2\%) (Hagmann, 2017d).

The metrics for the same subset of Twitter data from August 2017, received on October $12^{\text {th }}$ instead of September $4^{\text {th }}, 2017$, are little changed compared to the previous values (Figure 5). On average, 856.1 (std. dev. 1345.3) impressions (minimum: 193, maximum: 5558) and 16.0 (std. dev. 17.9) engagements (minimum: 2, maximum: 81 ) are recorded. The average engagement rate is 0.03 (std. dev. 0.01, minimum: 0.004 , maximum 0.06 ) or $3 \%$, the median engagement rate 0.02 (2\%) (Hagmann, 2017e).

Based on Twitter data derived from the period between November $23^{\text {rd }}$ and December 22 $2^{\text {nd }}, 2017$ and received from Twitter Analytics too, the Twitter audience target group of the RRL Twitter account can be described as followed: based on the interests of 165 followers on December 22 $2^{\text {nd }}, 2017$, the top interest (for $83 \%$ of followers) is within the category "science news", followed by "books-news and general info" (71\%) and "business and news" (60\%). Twitter followers are 
tweets 01/06/2017-22/09/2017

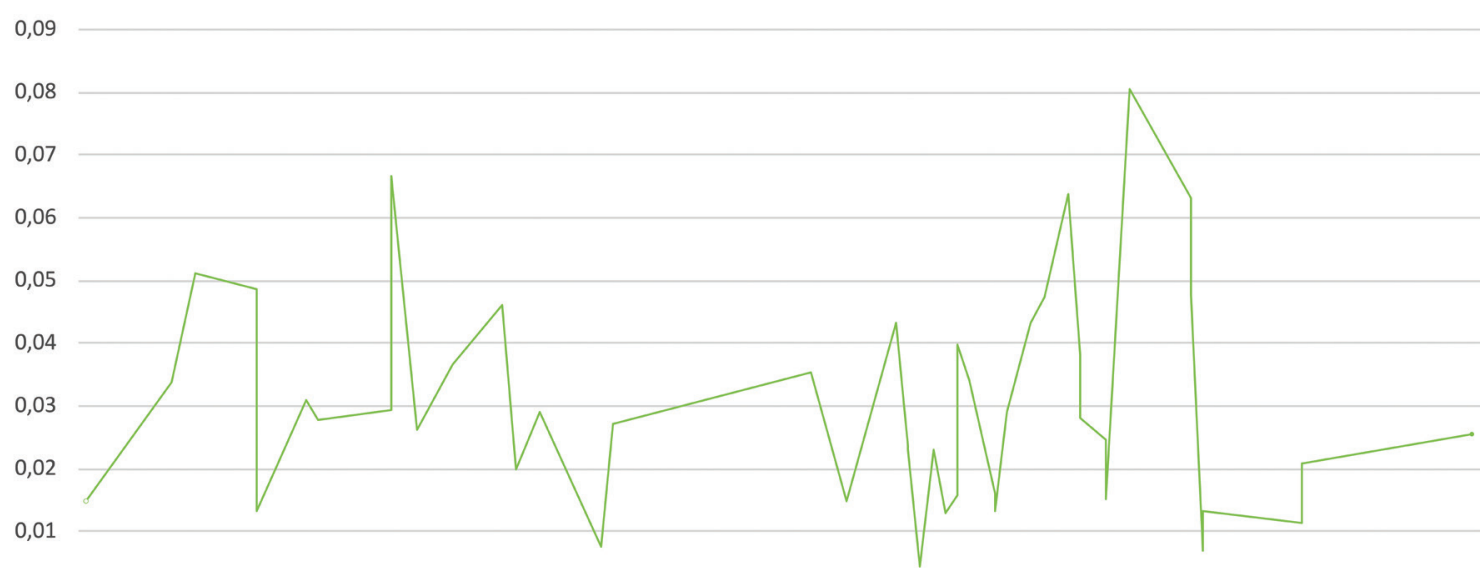

0

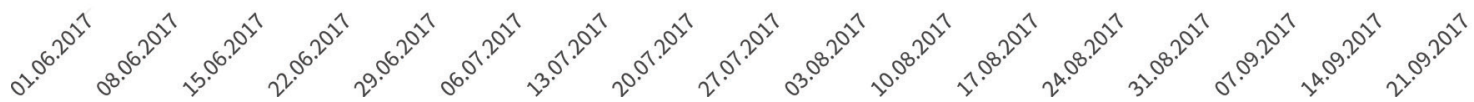

Figure 3. Engagement rate of the tweets $(n=46)$ from 2017-06-01 to 2017-09-22 (Dominik Hagmann, 2017. Data received from Twitter Analytics). tweets 08/2017 in 09/2017

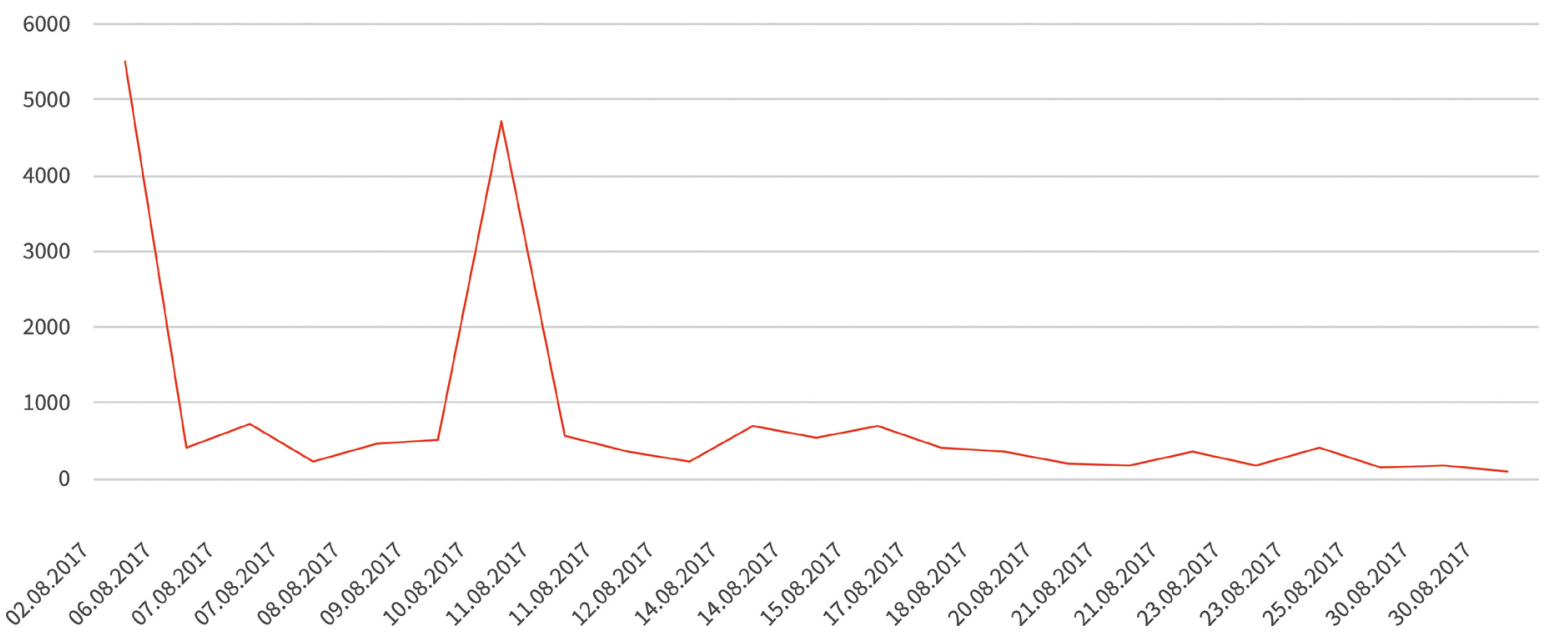

Figure 4. Impressions of the tweets (n=23) from 2017-08, downloaded on 2017-09-04 (Dominik Hagmann, 2017. Data received from Twitter Analytics).

tweets $08 / 2017$ in $10 / 2017$

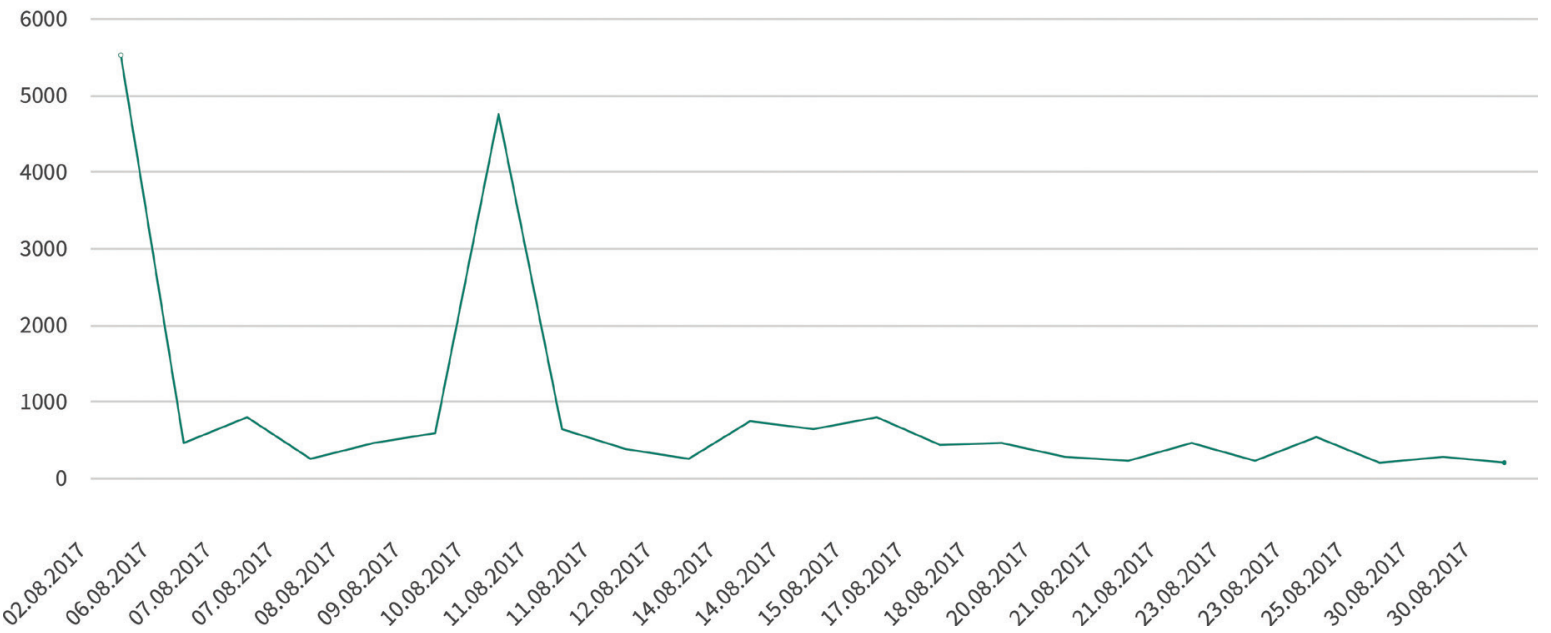

Figure 5. Impressions of the tweets ( $\mathrm{n}=23$ ) from 2017-08, downloaded on 2017-10-12 (Dominik Hagmann, 2017. Data received from Twitter Analytics). 
mainly from Austria, followed by users from Germany and the United Kingdom.

\section{Discussion}

A high variance in metrics can be clearly observed. Some tweets were shown 75 times on Twitter, others over 5000 times (Figure 1). While most of the impressions have a stable and uniform level of $c$. 600 , there are a few massive peaks of $c$. 5000, the lowest values being $c$. 100. The data peak was generated through an informal status update including a photo, while the lowest value is represented by a tweet with an embedded 3D model, meant for digital research data dissemination like the example shown above. So, the more data-related tweet has been far less successful regarding the number of times the tweet was shared. Compared to all tweets $(n=23)$ from August 2017 (retrieved on September $\left.9^{\text {th }}\right)$, tweet no. 892754365618028544 was extraordinarily successful with 5497 impressions and 82 engagements. However, the engagement rate of $0.015(1.5 \%)$ can be considered far below the average mean of $0.03(3 \%)$. Although tweet no. 902917404883394560 has a lower number of impressions (105) and engagements (5), all in all it has a significantly higher engagement rate of 0.05 (5\%) (Figures 2 and 3). The average engagement rate (c. $3 \%$ ) seems to be comparable to other science communication accounts on Twitter: A recently published study in medical sciences mentions an average engagement rate of 4.75 (median: 3.4\%) (Wadhwa et al., 2017). Aside from the contents of the tweets it seems to be of high importance which followers are retweeting: Tweet no. 892754365618028544 has been retweeted by the official Twitter account of the University of Vienna, for example, which resulted in many more impressions from its currently c. 10,800 Twitter followers (@univienna).

These two examples show that the use of integrated SNS for scientific research data dissemination has a lower absolute reach than tweets focusing on communicating actual fieldwork activities. Tweets focusing on pure research data dissemination may have much higher rates of interaction, due to the people actively engaging with the tweet. However, it is problematic that various engagements (likes, retweets, replies) may be performed by a single Twitter follower, so a seemingly high number of engagements may be based on an interaction with a relatively small number of users.

The metrics of the Twitter data presented are generated quite quickly. Looking at the same dataset from August 2017, again in September 2017, and again in October 2017, reveals that there is only moderate activity 30 days later (Figures 4, 5). In September 2017, c. 780 impressions per tweet could be recorded on average, while in October 2017 , this value was $c$. 850 . This is an average growth rate of $c .9 \%$. Therefore, there is some interest in older tweets, but most of the impressions refer to current tweets with no additional data peaks generated after one month. Accordingly, the engagements and the average engagement rate do not alter significantly.
All things considered, it is difficult to explain precisely why there are such high discrepancies in the Twitter metrics. Moreover, it is hard to decide which factors influence the perception and distribution of the tweets. One additional problem is that the algorithms which generate the Twitter timelines are not freely available. Finally, it must also be noted that the results presented here are primarily valid for the RRL Twitter account; therefore, it may be problematic to draw general conclusions using this dataset.

\section{Conclusion}

This study showed that scientific communication using integrated SNS is definitively possible and useful. Twitter is capable of data-driven science communication and, at least, it can be assumed that there is some stable perception of tweets on a certain level. It is also obvious that the sole use of integrated SNS as a dissemination tool for archaeological research is just one aspect among many possibilities. On the one hand, through integrating SNS like Twitter, Sketchfab, and ResearchGate into one dissemination tool, aboveaverage engagement rates were observed with relatively low values of impressions. On the other hand, through using Twitter as a pure microblogging platform as intended, relatively high numbers of impressions could be achieved, occasionally with below-average engagement rates.

It can be assumed that the more retweets that are made, the more impressions may be recorded per tweet (see Richardson, 2012). If accounts with numerous Twitter followers make these retweets, then the original tweets seem to be further promoted. As Richardson (2012) stated, it appears that on Twitter most of the interactions concerning research data dissemination are restricted to a core audience. Unsurprisingly, but worth mentioning, it looks like that the use of Twitter as a dissemination tool for specific archaeological data in the form of 3D models focuses more on communication within a small group of specialists (often knowing each other personally), rather than being a tool for broad science-to-public communication. Similarly, it may be true that this group of specialists is one that could use the data for scientific purposes. As Pilaar Birch (2013) mentioned, "this is not necessarily to be viewed as negative, as it depends on the intent of the project". Additionally, people who are interested in these datasets, such as researchers from other fields of science or science journalists, may also belong to this core audience. Alternatively, tweets which focus on actual archaeological fieldwork and which give insights into actual research activities do have the potential to gain much attention. That is why Twitter could very well serve as a tool for science-to-public communication.

Now we ask, are there only scientists reading the tweets and hopefully using the data, while "the public" simply just react on random tweets for no reason? Such posts used to be called cat content in German-speaking countries and contain messages like we wish you a pleasant weekend (e.g. Baumann, 2014; Firsching, 2017; Podhovnik, 2016). Is 
Twitter, then, just a tool for gaining attention as an application used for marketing only which serves to entertain followers? This seems hardly likely. Indeed, one must adapt contents carefully according to the targeted audience and the SNS used, mindful of the economic and administrative effort involved. Focusing on the desired target group, suitable contents must be found. These contents may be status updates which give insights to the role of cultural heritage and archaeology in general, tweets about research and fieldwork activities, and research data dissemination. (Deslis, 2012a; 2012b; Gruber, 2017; Colley, 2013; Kim, Cha, 2017).

It seems that there are chances to reach a small but engaged group of Twitter users at the time the tweet is posted. Furthermore, it must be noted that this small core audience also has to be enthusiastic about the tweets as well. This would manifest itself through commenting, liking and retweeting, because Twitter is always about interaction. In the end, however, it seems that SNS can be used as an integrated tool for scientist-to-scientist communication with no issue. Furthermore, depending on the content, these SNS are powerful tools for public archaeology itself (e.g. van den Dries, 2014; Gould, 2017; Grima, 2017; Hardy, 2015; Jensen, 2012; Matsuda, 2017; Moshenska, 2010; Richardson, Almansa-Sánchez, 2015).

There is simply not enough data yet to answer the abovementioned questions precisely. The observation period must be much longer and a significantly larger dataset must be checked to reveal the full potential of Twitter for archaeological outreach. To do so, further studies are planned: Firstly, a paper about the implementation of digital archaeology during the excavations and surveys at the Roman site of Molino San Vincenzo is going to be published in 2018/2019, incorporating data from Facebook, Twitter and YouTube, and serving as an example of the use of personal accounts in digital science communication. Secondly, to make further data available, an additional paper is planned for 2020, offering critical evaluations of the utility of different SNS for science communication and data dissemination within digital archaeology, based on individual and institutional user accounts. The study presented here is thus only a first step in a multistage case study on digital public archaeology.

Returning to the question mentioned at the beginning of the article, currently there is no need to start a Twitter war or engage in other active communication strategies to successfully disseminate archaeological information. Indeed, everything seems to depend - quite unsurprisingly - on a clearly defined social media strategy. Moreover, one should adapt the contents to the desired target group, and attracting and using the reach of active followers is of utmost importance. With this as the main consideration, the presented dissemination strategy should be suitable to the unique goals of digital archaeology and may in turn enable fruitful science communication. The above-mentioned additional research will test this assumption.

\section{Acknowledgements}

First of all, I want to thank Günther Schörner for realising the whole project "Molino San Vincenzo". Nisa Iduna Kirchengast helped me a lot managing the social media channels, and that is why I owe her sincere thanks. Furthermore, I want to thank Katharina Rebay-Salisbury, Roderick Salisbury, and Estella Weiss-Krejci, as well as their team, for organising the CETAG conference "Disciplinarity in Archaeology" held at the Institute for Oriental and European Archaeology (OREA) at the Austrian Academy of Science (ÖAW) in Vienna, where this paper was originally presented in 2017. I also thank Christoph Schwall for supporting me at this event (thanks for the print-out!). Moreover, I want to thank all the students and co-workers who have participated at the project in Tuscany since 2012. The whole study presented was funded by the Austrian Science Fund (FWF; stand-alone project P 27476 "Val di Pesa and Val Orme as a Changing Rural Landscape: an integrated approach"), and by the Department of Classical Archaeology, as well as the Faculty of Historical and Cultural Studies (Claudia Theune-Vogt) at the University of Vienna. Furthermore, I thank the Soprintendenza per i Beni Archeologici della Toscana (especially Lorella Alderighi and Barbara Arbeid) and the Associazione Archeologica Volontariato Medio Valdarno (Leonardo Terreni), as well as Sketchfab Inc. (Nicolas Guinebretière). Last but not least, I wish to express special thanks to the two reviewers who gave me valuable support and helpful inputs for this paper and to Folkert Tiarks (www.toptransarchaeo.de) for proof-reading the manuscript.

\section{References}

\#PATC. Public Archaeology Twitter Conference, 2017. https:// publicarchaeologyconference.wordpress.com/ Accessed 14.12.2017.

(a) bednarz, 2017a. Short message on Twitter from the user "Bednarz O'Connell”, 2017-09-13. https://twitter.com/bednarz/ status/907910712646934528 Accessed 16.12.2017.

@ bednarz, 2017b. Twitter account of “Bednarz O’Connell”. https://twitter. com/bednarz Accessed 16.12.2017.

(a)buster, 2014. Introducing organic Tweet analytics, Twitter blog (201407-11). https://blog.twitter.com/marketing/en_us/a/2014/introducingorganic-tweet-analytics.html Accessed 22.12.2017.

\#CAATCO, 2018. First CAA Twitter Conference 2018. https:// caatwitterconference.wordpress.com/ Accessed 06.02.2018.

(a)denmarkdotdk, 2016a. Short message on Twitter from the user "Denmark.dk", 2016-07-07. https://twitter.com/denmarkdotdk/ status/750982567457882112 Accessed 16.12.2017.

(a)denmarkdotdk, 2016b. Short message on Twitter from the user "Denmark.dk", 2016-07-07. https://twitter.com/denmarkdotdk/ status/750972329782550528 Accessed 11.12.2017.

(a)denmarkdotdk, 2017. Twitter account of "Denmark.dk". https://twitter. com/denmarkdotdk Accessed 16.12.2017.

@rrl_univie, 2017a. Short message on Twitter from the user "RomanRuralLandscapes", 2017-08-02. https://twitter.com/rrl_univie/ status/892754365618028544 Accessed 28.12.2017.

(a)rrl_univie, 2017b. Short message on Twitter from the user "RomanRuralLandscapes", 2017-08-30. https://twitter.com/rrl_univie/ status/902917404883394560 Accessed 20.12.2017. 
(a)rrl univie, 2017c. Short message on Twitter from the user "RomanRuralLandscapes", 2017-10-12. https://twitter.com/rrl_univie/ status/918476547908161536 Accessed 21.12.2017.

@ swendense, 2016a. Short message on Twitter from the user "Denmark.dk", 2016-07-07. https://twitter.com/swedense/status/750974566369988608 Accessed 16.12.2017.

(a) swendense, 2016b. Short message on Twitter from the user "Sweden.se", 2016-07-07. https://twitter.com/swedense/status/750970203564105728 Accessed 16.12.2017.

@ swendense, 2016c. Short message on Twitter from the user "Sweden.se", 2016-07-07. https://twitter.com/swedense/status/750972659526164480 Accessed 11.12.2017.

@swendense, 2017. Twitter account of "Sweden.se". https://twitter.com/ swedense Accessed 16.12.2017

(a)TwitterNotify, 2017. Short message on Twitter from the user "Twitter Notify", 2017-09-26. https://twitter.com/TwitterNotify/ status/912740360488718336 Accessed 16.12.2017.

@univienna: Twitter account of "Universität Wien". https://twitter.com/ univienna/ Accessed 28.12.2017.

Adobe: Illustrator CC 2017. http://www.adobe.com/uk/products/illustrator. html Accessed 21.12.2017.

Agisoft PhotoScan 2017. http://www.agisoft.com/ Accessed 21.12.2017.

AHMAD, A. N., 2010. Is Twitter a Useful Tool for Journalists? Journal of Media Practice 11(2), 145-155. http://dx.doi.org/10.1386/ jmpr.11.2.145 1 Accessed 14.12.2017.

ALAIMO, K., 2017. How to Wage Twitter War for Fun and Profit (Bloomberg). https://www.bloomberg.com/view/articles/2017-09-23/ how-to-wage-twitter-war-for-fun-and-profit Accessed 12.12.2017.

BAIR, S., CARLSON, S., 2008. Where Keywords Fail: Using Metadata to Facilitate Digital Humanities Scholarship. Journal of Library Metadata 8(3) 249-262

http://dx.doi.org/10.1080/19386380802398503 Accessed 05.03.2018.

BALL, J. R., 2013. Staging the Twitter War: Toneelgroep Amsterdam's Roman Tragedies. The Drama Review 57(4), 163-170. http://dx.doi. org/10.1162/DRAM a 00309 Accessed 12.12.2017.

BANKS , I., KOSKINEN-KOIVISTO, E., SEITSONEN, O., 2017. Public Engagements with Lapland's Dark Heritage: Community Archaeology in Finnish Lapland. Journal of Community Archaeology \& Heritage, 1-10. http://dx.doi.org/10.1080/20518196.2017.1383672 Accessed 28.12.2017.

BAUER, B., BLECHL, G., BOCK, C., DANOWSKI, P., FERUS, A., GRASCHOPF, A., KÖNIG, T., MAYER, K., RECKLING, F., RIECK, K., SEITZ, P., STÖGER, H., WELZIG, E., 2015. Empfehlungen für die Umsetzung von Open Access in Österreich: Arbeitsgruppe „Nationale Strategie“ des Open Access Network Austria (OANA). http://dx.doi. org/10.5281/zenodo.33178, zuletzt aktualisiert am 2015 Accessed 16.12.2017.

BAUMANN, P., 2014. Cat Content und die schizophrene deutsche Social Media-Landschaft, 2014-08-04 (Netzrunde - Ein Gott und die Welt Blog). http://www.netzrunde.de/catcontent-und-die-schizophrenedeutsche-social-media-landschaft/ Accessed 18.12.2017.

BERNACKI, J., BŁAŻEJCZYK, I., INDYKA-PIASECKA, A., KOPEL, M., KUKLA, E., TRAWIŃSKI, B., 2016. Responsive Web Design: Testing Usability of Mobile Web Applications. In: N. T. Nguyen, B. Trawiński, H. Fujita, T.-P. Hong eds. Intelligent Information and Database Systems: $8^{\text {th }}$ Asian Conference, ACIIDS 2016, Da Nang. Vietnam, March 14-16, 2016, Proceedings, Part I. Berlin: Springer, pp. 257-269. http://dx.doi.org/10.1007/978-3-662-49381-6_25 Accessed 22.12.2017.

BERNERS-LEE, T., 1997. Links and Law. https://www.w3.org/ DesignIssues/LinkLaw Accessed 17.12.2017.

BERNERS-LEE, T., CAILliAU, R., LUOTONEN, A., NIELSEN, H. F., SECRET, A., 1994. The World-Wide Web. Communications of the ACM 37(8), 76-82. http://dx.doi.org/10.1145/179606.179671 Accessed 17.12.2017.

BERRY, D. M., 2012. Introduction: Understanding the Digital Humanities. In: D. M. Berry, ed. Understanding Digital Humanities, New York: Palgrave Macmillan. Houndmills, pp. 1-20. http://dx.doi. org/10.1057/9780230371934 1 Accessed 05.03.2018.

BETTS, M.W., MASCHNER, H.D.G., SCHOU, C.D., SCHLADER, R., HOLMES, J., CLEMENT, N., SMUIN, M., 2011. Virtual
Zooarchaeology: Building a Web-based Reference Collection of Northern Vertebrates for Archaeofaunal Research and Education. Journal of Archaeological Science 38(4), 755.e1-755.e9. http://dx.doi. org/10.1016/j.jas.2010.06.021 Accessed 28.12.2017.

BOL, G., 2010. Deskriptive Statistik. Berlin, Boston: De Gruyter.

BORREGO, Á., 2017. Institutional Repositories versus ResearchGate: The Depositing Habits of Spanish Researchers. Learned Publishing 30(3), 185-192. http://dx.doi.org/10.1002/leap.1099 Accessed 14.12.2017.

BRIN, A., MCMANAMON, F.P., NIVEN, K., 2013. Caring for Digital Data in Archaeology: A Guide to Good Practice. Oxford, Oakville: Oxbow, Archaeology Data Service and Digital Antiquity.

BRUNS, A., MOON, B., PAUL, A., MÜNCH, F., 2016. Towards a Typology of Hashtag Publics: A Large-scale Comparative Study of User Engagement Across Trending Topics. Communication Research and Practice 2(1), 20-46. http://dx.doi.org/10.1080/22041451.2016.115532 8 Accessed 28.12.2017.

BURDICK, A., 2012. Digital_Humanities. Cambridge: MIT Press.

CAA International 2017. Published CAA Proceedings. http://caainternational.org/proceedings/published/ Accessed 18.12.2017.

CAMPBELL, H., ed. 2015. Digital Judaism: Jewish Negotiations with Digital Media and Culture. 1st ed. New York: Routledge. Routledge studies in religion and digital culture 2.

CANCRO, P., 2016. The Dark(ish) Side of Digitization: Information Equity and the Digital Divide. The Serials Librarian 71(1), 57-62. http://dx.doi. org/10.1080/0361526X.2016.1157424 Accessed 28.12.2017.

CAVANILlAS, J.M., CURRY, E., WAHLSTER, W., 2016. New Horizons for a Data-Driven Economy. Cham: Springer. http://dx.doi. org/10.1007/978-3-319-21569-3 Accessed 28.12.2017.

COLLADA. 3D Asset Exchange Schema 2017. https://www.khronos.org/ collada/ Accessed 21.12.2017.

COLLEY, S., 2013. Social Media and Archaeological Communication: An Australian Survey. Archäologische Informationen 36(1), 65-80. http:// dx.doi.org/10.11588/ai.2013.0.15385 Accessed 19.12.2017.

COMUNELLO, F., ANZERA, G., 2012. Will the Revolution be Tweeted?:A Conceptual Framework for understanding the social media and the Arab Spring. Islam and Christian-Muslim Relations 23(4), 453-470. http:// dx.doi.org/10.1080/09596410.2012.712435 Accessed 28.12.2017.

CONOLE, G., DYKE, M., 2016. What are the Affordances of Information and Communication Technologies? ALT-J 12(2), 113-124. http://dx.doi. org/10.1080/0968776042000216183.

COSTOPOULOS, A., 2016. Digital Archeology Is Here (and Has Been for a While). Frontiers in Digital Humanities 3, 8. http://dx.doi.org/10.3389/ fdigh.2016.00004 Accessed 28.12.2017.

Creative Commons: Attribution 4.0 International License, 2017. https:// creativecommons.org/licenses/by/4.0/ Accessed 22.12.2017.

DALY, P. T., EVANS, C., 2006. Introduction: Archaeological Theory and Digital Pasts. In: T. L. Evans, P. T. Daly, eds. Digital archaeology: Bridging Method and Theory. London, New York: Routledge, 2-7.

DENNING, K., 2004. "The Storm of Progress" and Archaeology for an Online Public. Internet Archaeology 15(1). http://dx.doi.org/10.11141/ ia.15.1 Accessed 18.12.2017.

DESLIS, J., 2012a. Academic Communication Via Facebook and Twitter In: P. Stockinger, ed. Digital audiovisual archives. London: ISTE Ltd., 141-168. http://dx.doi.org/10.1002/9781118561997.ch6 Accessed 28.12.2017.

DESLIS, J., 2012b. Uses for Digital Content Sharing Platforms. In: P. Stockinger, ed. Digital audiovisual archives. London: ISTE Ltd., 169-188. http://dx.doi.org/10.1002/9781118561997.ch7 Accessed 28.12.2017.

dha. Digital Humanities Austria, 2017. http://www.digital-humanities.at/de Accessed 16.12.2017.

DHd, 2018 Köln. 5. Tagung der Digital Humanities im deutschsprachigen Raum, Köln 26.02. - 02.03.2018 2017. http://dhd2018.uni-koeln.de/ Accessed 18.12.2017

DIAO, J., HERNÁNDEZ, M.A., 2014. Transferring Cataloging Legacies into Descriptive Metadata Creation in Digital Projects: Catalogers' Perspective. Journal of Library Metadata 14(2) 130-145. http://dx.doi.or g/10.1080/19386389.2014.909670 Accessed 05.03.2018.

DIXON, M., 2013. Ask A Curator Day Sept 17 $7^{\text {th }}$ \#AskACurator @ AskaCurator, 2013-08-27. http://www.mardixon.com/wordpress/2013/08/ ask-a-curator-day-sept-18th-2013-askacurator/ Accessed 18.12.2017. 
DJINDJIAN, F., 1998. GIS Usage in Worldwide Archaeology. Archeologia e Calcolatori 9, 19-29. http://www.archcalc.cnr.it/indice/PDF9/09_03_ Djindjian.pdf Accessed 18.12.2017.

DJINDJIAN, F., 2015. Computers and Mathematics in Archaeology, Anatomy of an Ineluctable Success! In: F. Giligny, F. Djindjian, L. Costa, P. Moscati, S. Robert, eds. CAA $2014-21^{\text {st }}$ Century Archaeology: Proceedings of the 42 ${ }^{\text {nd }}$ Annual Conference on Computer Applications and Quantitative Methods in Archaeology. Oxford: Archaeopress, 1-6.

DOI. Digital Object Identifier System, 2017. https://www.doi.org/ Accessed 21.12.2017.

Dominik Hagmann. Homepage, 2017. http:/homepage.univie.ac.at/ dominik.hagmann/ Accessed 21.12.2017.

EBERSBACH, A., GLASER, M., HEIGL, R., 2016. Social Web. $3^{\text {rd }}$ ed. Konstanz: UVK Verlagsgesellschaft GmbH, UTB 3065.

ENLI, G., SIMONSEN, C.-A., 2017. "Social Media Logic" Meets Professional Norms: Twitter Hashtags Usage by Journalists and Politicians. Information, Communication \& Society 44(2), 1-16. http:// dx.doi.org/10.1080/1369118X.2017.1301515 Accessed 14.12.2017.

EVANS, C., 2014. Twitter for Teaching: Can Social Media be Used to Enhance the Process of Learning? British Journal of Educational Technology 45(5), 902-915. http://dx.doi.org/10.1111/bjet.12099 Accessed 14.12.2017.

Excel, 2017a. AVERAGE function. https://support.office.com/engb/article/AVERAGE-function-047BAC88-D466-426C-A32B8F33EB 960CF6? omkt $=$ en-GB\&ui $=$ en-US\&rs $=$ en $-\mathrm{GB} \& \mathrm{ad}=\mathrm{GB}$ Accessed 20.12.2017.

Excel, 2017b. MEDIAN function. https://support.office.com/ en-us/article/MEDIAN-function-d0916313-4753-414c-8537ce85bdd967d2?omkt=en-001\&ui=en-US\&rs=en-001\&ad=US Accessed 28.12.2017.

Excel, 2017c: STDEV.P function. https://support.office.com/en-gb/article/ STDEV-P-function-6e917c05-31a0-496f-ade7-4f4e7462f285?omkt=enGB\&ui $=$ en-US\&rs $=$ en-GB\&ad $=$ GB Accessed 20.12.2017.

FARWELL, J.P., 2014. The Media Strategy of ISIS. Survival 56(6), 49-55. http://dx.doi.org/10.1080/00396338.2014.985436 Accessed 12.12.2017.

FIRSCHING, J., 2017. Mehr als Cat Content und Selfies: Erfolgreiches Instagram Marketing für Unternehmen. In: H. Scholz, ed. Social goes Mobile - Kunden gezielt erreichen: Mobile Marketing in Sozialen Netzwerken. $2^{\text {nd }}$ ed. Wiesbaden: Springer, 85-103. http://dx.doi. org/10.1007/978-3-658-16604-5_6 Accessed 17.12.2017.

FUNKHOUSER, T., SHIN, H., TOLER-FRANKLIN, C., CASTATÑEDA, A.G., BROWN, B., DOBKIN, D., RUSINKIEWICZ, S., WEYRICH, T., 2011. Learning How to Match Fresco Fragments. Journal on Computing and Cultural Heritage 4(2) 1-13. http://dx.doi. org/10.1145/2037820.2037824 Accessed 05.03.2018.

GABELlONE, F., 2015. Digital Technologies and Communication: Prospects and Expectations. Open Archaeology 1(1), 291. http://dx.doi. org/10.1515/opar-2015-0005 Accessed 28.12.2017.

GANAHL, R., 2013. The Social Media War: Is Google+ the David to Facebook's Goliath? In: M. Friedrichsen, W. Mühl-Benninghaus, eds. Handbook of Social Media Management: Value Chain and Business Models in Changing Media Markets. Berlin, Heidelberg: Springer, 513-531. http://dx.doi.org/10.1007/978-3-642-28897-5_30 Accessed 28.12.2017.

GENNARO, S., 2015. Scientists and Social Media. Journal of Nursing Scholarship 47(5), 377-378. http://dx.doi.org/10.1111/jnu.12161 Accessed 28.12.2017.

GHILARDI, M., DESRUELLES, S., 2009. Geoarchaeology: Where Human, Social and Earth Sciences Meet with Technology. S.A.P.I.EN.S - Surveys and Perspectives Integrating Environment and Society 2(2). http://sapiens.revues.org/422 Accessed 21.12.2017.

Google Maps. Molino San Vincenzo, 2017. https://www.google.at/ maps/place/Molino+San+Vincenzo/@43.6945404,11.0951942, $16.25 \mathrm{z} /$ data $=! 4 \mathrm{~m} 5$ ! $3 \mathrm{~m} 4$ ! $1 \mathrm{~s} 0 \times 132 \mathrm{a} 44 \mathrm{c} 745 \mathrm{e} 39 \mathrm{fef}: 0 \times$ fe $591 \mathrm{cfc} 00 \mathrm{e} 43$ a2f!8m2!3d43.6941872!4d11.0948521 Accessed 21.12.2017.

GOULD, P.G., 2017. On the Case: Method in Public and Community Archaeology. Public Archaeology 15(1), 5-22. http://dx.doi.org/10.108 0/14655187.2016.1199942 Accessed 28.12.2017.

GREGORY, I., 2014. Challenges and Opportunities for Digital History. Frontiers in Digital Humanities 1, 45. http://dx.doi.org/10.3389/ fdigh.2014.00001 Accessed 28.12.2017.
GRAHAM, S., MILliGAN, I., WEINGART, S., 2016. Exploring Big Historical Data: The Historian's Macroscope. London, Hackensack: Imperial College Press; Distributed by World Scientific Publishing Co. Pte. Ltd.

GRIMA, R., 2017. But Isn't All Archaeology "Public" Archaeology? Public Archaeology 15(1), 50-58. http://dx.doi.org/10.1080/14655187.2 016.1200350 Accessed 11.12.2017.

GROSMAN, L., 2016. Reaching the Point of No Return: The Computational Revolution in Archaeology. Annual Review of Anthropology 45(1), 129145. http://dx.doi.org/10.1146/annurev-anthro-102215-095946 Accessed 16.12.2017.

GRUBER, G., 2017. Contract Archaeology, Social Media and the Unintended Collaboration with the Public: Experiences from Motala, Sweden. Internet Archaeology 22(46), 157. http://dx.doi.org/10.11141/ ia.46.5 Accessed 28.12.2017.

HAGMANN, D., 2017a. The Digital Archaeology Collection on ScienceOpen. http://dx.doi.org/10.14293/S2199-1006.1.SOR-SOCSCI. CLKKKFR.v1 Accessed 17.12.2017.

HAGMANN, D., 2017b. The Digital Archaeology Collection on ScienceOpen: Editorial. ScienceOpen Research. http://dx.doi. org/10.14293/S2199-1006.1.SOR-SOCSCI.ET5WRO.v1 Accessed 17.12.2017.

HAGMANN, D., 2017c. Twitter data 2017-06-01 - 2017-09-22. http:// phaidra.univie.ac.at/o:607323 Accessed 21.12.2017.

HAGMANN, D., 2017d. Twitter data 2017-08 (2017-09-04). http://phaidra. univie.ac.at/o:607324 Accessed 21.12.2017.

HAGMANN, D., 2017e. Twitter data 2017-08 (2017-10-12). http://phaidra. univie.ac.at/o:607325 Accessed 21.12.2017.

HAGMANN, D., 2017f. Webseiten. In: M. Heinrich, F. Schäfer, M. Trognitz, eds. IT-Empfehlungen für den nachhaltigen Umgang mit digitalen Daten in den Altertumswissenschaften: Version 1.0.0.0, 29.03.2017. IANUS FDZ Archäologie \& Altertumswissenschaften, 207-227. http://dx.doi. org/10.13149/000.y47clt-t Accessed 17.12.2017.

HAGMANN, D., REITER, J., 2016a. Molino San Vincenzo: 3D Model of trench 2/2014 | 3D Model (2016-11-04). http://dx.doi.org/10.13140/ RG.2.2.33108.50565 Accessed 21.12.2017.

HAGMANN, D., REITER, J., 2016b. Molino San Vincenzo: 3D Model of trench 2/2014 | Texture (2016-11-04). http://dx.doi.org/10.13140/ RG.2.2.16331.28967 Accessed 21.12.2017.

HAGMANN,D., REITER,J.,2016c.MolinoSanVincenzoS2/2014(2016-0608). https://sketchfab.com/models/47ec8c73698f4156a6fdb00b $9 f 193 \mathrm{dc} 0$ Accessed 21.12.2017.

HAGMANN, D., SCHÖRNER, G., SCHRECK, V., 2015. Die site Molino San Vincenzo. Archäologie Österreichs 26(2), 56-59. http://dx.doi. org/10.17613/M6W54F Accessed 21.12.2017.

HARDY, M.D., 2015. The Southeast Archeological Center at 50: New Directions towards Community Engagement and Heritage Education. Journal of Community Archaeology \& Heritage 2(3), 208-220. http:// dx.doi.org/10.1179/2051819615Z.00000000043 Accessed 28.12.2017.

HENSON, D., 2013. Digital Media and Public Engagement in Archaeology: An Opinion Piece. Archäologische Informationen 36(1), 13-20. http:// dx.doi.org/10.11588/ai.2013.0.15379 Accessed 19.12.2017.

HIRST, K., 2008. Archaeology Today. In: D.M. Pearsall, ed. Encyclopedia of archaeology. San Diego, Calif.: Elsevier, 478-489. https://doi. org/10.1016/B978-012373962-9.00176-X Accessed 16.12.2017.

HOOKK, D.Y., 2016. From Illusions to Reality: Transformation of the Rerm "Virtual Archaeology". Archaeological and Anthropological Sciences 8(4), 647-650. http://dx.doi.org/10.1007/s12520-014-0201-8 Accessed 16.12.2017.

HUFFER, D., GRAHAM, S., 2017. The Insta-Dead: The rhetoric of the human remains trade on Instagram. Internet Archaeology 2(45), 1. http:// dx.doi.org/10.11141/ia.45.5 Accessed 05.02.2018.

HUGGETT, J., 2015a. A Manifesto for an Introspective Digital Archaeology. Open Archaeology 1(1), 193. http://dx.doi.org/10.1515/ opar-2015-0002 Accessed 28.12.2017.

HUGGETT, J., 2015b. Challenging Digital Archaeology. Open Archaeology 1(1), 193. http://dx.doi.org/10.1515/opar-2015-0003 Accessed 28.12.2017.

HUGGetT, J., 2017. The Apparatus of Digital Archaeology. Internet Archaeology 15(44), 57. http://dx.doi.org/10.11141/ia.44.7 Accessed 28.12.2017. 
HUVILA, I., 2013. Engagement Has its Consequences: The Emergence of the Representations of Archaeology in Social Media. Archäologische Informationen 36(1), 21-30. http://dx.doi.org/10.11588/ai.2013.0.15382 Accessed 14.12.2017.

JANNIDIS, F., KOHLE, H., REHBEIN, M., ed., 2017. Digital Humanities, Stuttgart: J.B. Metzler. https://doi.org/10.1007/978-3-476-05446-3 Accessed 16.12.2017.

JEFFREY, S., 2012. A new Digital Dark Age? Collaborative Web Tools, Social Media and Long-term Preservation. World Archaeology 44(4), 553-570. http://dx.doi.org/10.1080/00438243.2012.737579 Accessed 14.12.2017.

JENSEN, A.M., 2012. Culture and change: Learning from the past through Community Archaeology on the North Slope. Polar Geography 35(3-4), 211-227. http://dx.doi.org/10.1080/1088937X.2012.710881 Accessed 28.12.2017.

JONES, N., BAINES, P., 2013. Losing Control?: Social Media and Military Influence. The RUSI Journal 158(1), 72-78. http://dx.doi.org/10.1080/03 071847.2013.774643 Accessed 12.12.2017.

JPEG, 2017. https://jpeg.org/ Accessed 21.12.2017.

KANSA, E.C., KANSA, S.W., ARBUCKLE, B., 2014. Publishing and Pushing: Mixing Models for Communicating Research Data in Archaeology. International Journal of Digital Curation 9(1). http:// dx.doi.org/10.2218/ijdc.v9i1.301 Accessed 28.12.2017.

KANSA, E.C., KANSA, S.W., WATRALL, E., 2012. Archaeology 2.0: New Tools for Communication and Collaboration. Cotsen Digital Archaeology 1. Los Angeles, Oxford: Oxbow.

KAPLAN, F., 2015. Frontiers in Digital Humanities: The Road Ahead (frontiers Blog). https://blog.frontiersin.org/2015/07/08/frontiers-indigital-humanities-the-road-ahead/ Accessed 16.12.2017.

KEHRBERG, A.K., 2015. "I Love You, Please Notice Me": The Hierarchical Rhetoric of Twitter Fandom. Celebrity Studies 6(1), 85-99. http://dx.doi.org/10.1080/19392397.2015.995472 Accessed 14.12.2017.

KEKES J., 2010. War. Philosophy 85(332), 201-218. http://dx.doi. org/10.1017/S0031819110000045 Accessed 11.12.2017.

KERKMANN, F., LEWANDOWSKI, D., 2015. Barrierefreie Informationssysteme: Zugänglichkeit für Menschen mit Behinderung in Theorie und Praxis. Age of access? 6. Berlin, Boston: De Gruyter.

KIM, M., CHA, J., 2017. A Comparison of Facebook, Twitter, and LinkedIn: Examining Motivations and Network Externalities for the Use of Social Networking Sites. First Monday 22(11). http://dx.doi. org/10.5210/fm.v22i11.8066 Accessed 28.12.2017.

KLAUSEN, J., 2014. Tweeting the Jihad: Social Media Networks of Western Foreign Fighters in Syria and Iraq. Studies in Conflict \& Terrorism 38(1), 1-22. http://dx.doi.org/10.1080/1057610X.2014.974948 Accessed 12.12.2017.

KOBILKE, K., 2016. Erfolgreich mit Instagram: Mehr Aufmerksamkeit mit Fotos \& Videos. $2^{\text {nd }}$ ed. Frechen: MITP.

KOHN, S., 2015. "Star Wars" Trailer, Race and the Ugly Forces of Twitter $(\mathrm{CNN})$. https://edition.cnn.com/2015/10/20/opinions/kohn-star-warsrace-tweets/index.html Accessed 06.02.2018.

KOWALCZYK, S.T., 2014. Where Does All the Data Go: Quantifying the Final Disposition of Research Data. Proceedings of the American Society for Information Science and Technology 51(1), 1-10. http://dx.doi. org/10.1002/meet.2014.14505101044 Accessed 14.12.2017.

LÄHTEENMÄKI, I., VIRTA, T., 2016. The Finnish Twitter War: The Winter War Experienced Through the \#sota39 Project and Its Implications for Historiography. Rethinking History 20(3), 433-453. http://dx.doi.org/ 10.1080/13642529.2016.1192259 Accessed 28.12.2017.

LAKE, M., 2012. Open Archaeology. World Archaeology 44(4), 471-478. http://dx.doi.org/10.1080/00438243.2012.748521 Accessed 22.12.2017.

LANGENDORF, A., HAGMANN, D., SCHÖRNER, G., 2017. Die Fundplätze Albersdorf und Oberaustall (Modeling Roman Rural Landscapes Project): Erste geomagnetische Prospektionen. In: F. Lang, S. Traxler, R. Kastler, eds. Neue Forschungen zur ländlichen Besiedlung in Nordwest-Noricum. Salzburg: Universität Salzburg, Fachbereich Altertumswissenschaften, 203-213. http://dx.doi.org/10.17613/ M6DR5B Accessed 17.12.2017.

LARACUENTE, N.R., 2016. Public Archaeology 2.0: Facilitating Engagement with Twitter. AP: Online Journal in Public Archaeology 2, 81. http://dx.doi.org/10.23914/ap.v2i0.15 Accessed 14.12.2017.

LAWSON, S., 2014. The US Military's Social Media Civil War: Technology as Antagonism in Discourses of Information-age Conflict. Cambridge Review of International Affairs 27(2), 226-245. http://dx.doi.org/10.1080 /09557571.2012.734787 Accessed 12.12.2017.

LEVY, T.E., 2014. From the Guest Editor. Near Eastern Archaeology 77(3). http://dx.doi.org/10.5615/neareastarch.77.3.fm Accessed 28.12.2017.

LLOYD, J., 2016. Contextualizing 3D Cultural Heritage. In: M. Ioannides, E. Fink, A. Moropoulou, M. Hagedorn-Saupe, A. Fresa, G. Liestøl et al., eds. Digital Heritage. Progress in Cultural Heritage: Documentation, Preservation, and Protection: $6^{\text {th }}$ International Conference, EuroMed 2016, Nicosia, Cyprus, October 31 - November 5, 2016, Proceedings, Part I. Cham: Springer, 859-868. http://dx.doi.org/10.1007/978-3-31948496-9 69 Accessed 28.12.2017.

MANO, R.S., 2012. Digital Communication and Performance in Nonprofit Settings: A Stakeholders' Approach. In: C. Palanisamy, ed. Digital Communication. Rijeka: InTech, 29-40. http://dx.doi.org/10.5772/38645 Accessed 19.12.2017

MANOVICH,L., 2012. How to Compare One Million Images? In:D.M. Berry, ed. Understanding Digital Humanities. Houndmills, New York: Palgrave Macmillan, 249-278. http://dx.doi.org/10.1057/9780230371934_14 Accessed 05.03.2018.

MATSUDA, A., 2017. A Consideration of Public Archaeology Theories. Public Archaeology 15(1), 40-49. http://dx.doi.org/10.1080/14655187.2 016.1209377 Accessed 28.12.2017.

Microsoft. Excel, 2016, 2017. https://products.office.com/en-gb/excel Accessed 21.12.2017.

MILES, D., 2004. Preface: Digital Dissemination and Archiving. Internet Archaeology 15(1). http://dx.doi.org/10.11141/ia.15.12 Accessed 16.12.2017.

Molino San Vincenzo, 2017. https://rrl.univie.ac.at/forschung/msv/ Accessed 21.12.2017.

MOON, J.H., LEE, E., LEE, J.-A., CHOI, T.R., SUNG, Y., 2016. The Role of Narcissism in Self-promotion on Instagram. Personality and Individual Differences 101, 22-25. http://dx.doi.org/10.1016/j.paid.2016.05.042 Accessed 28.12.2017.

MORGAN,C.,2015.ArchaeologyandtheMovingImage.PublicArchaeology 13(4), 323-344. http://dx.doi.org/10.1179/1465518715Z.00000000077 Accessed 16.12.2017.

MORGAN, C., EVE, S., 2012. DIY and Digital Archaeology: What Are You Doing to Participate? World Archaeology 44(4), 521-537. http:// dx.doi.org/10.1080/00438243.2012.741810 Accessed 14.12.2017.

MOSHENSKA, G., 2010. What is Public Archaeology? Present Pasts 1. http://dx.doi.org/10.5334/pp.7 Accessed 14.12.2017.

MURRIETA-FLORES, P., DONALDSON, C., GREGORY, I., 2017. Advancing Digital Humanities Research Through the Spatial Analysis of Historical Travel Writing and Topographical Literature. digital humanities quaterly 11(1). http://www.digitalhumanities.org/dhq/ vol/11/1/000283/000283.html Accessed 21.12.2017.

NEAL, D.R., 2012. Introduction. In: D.R. Neal, ed. Social Media for Academics: A Practical Guide. Oxford: Chandos Publishing. 23-28.

NICHOLAS, D., CLARK, D., HERMAN, E., 2016. ResearchGate: Reputation Uncovered. Learned Publishing 29(3), 173-182. http:// dx.doi.org/10.1002/leap.1035 Accessed 14.12.2017.

NICHOLS, S.G., ALTSCHUL, N.R., 2012. Digital Philology: A Journal of Medieval Cultures. Digital Philology: A Journal of Medieval Cultures 1(1), 1-2. http://dx.doi.org/10.1353/dph.2012.0007 Accessed 28.12.2017.

NIYAZOV, Y., VOGEL, C., PRICE, R., LUND, B., JUDD, D., AKIL, A., MORTONSON, M., SCHWARTZMAN, J., SHRON, M., 2016. Open Access Meets Discoverability: Citations to Articles Posted to Academia. edu. PloS one 11(2), e0148257. http://dx.doi.org/10.1371/journal. pone.0148257 Accessed 28.12.2017.

ORABY, S., GUNDECHA, P., MAHMUD, J., BHUIYAN, M., AKKIRAJU, R., 2017. "How May I Help You?”. In: G.A. Papadopoulos, ed. IUI'17: Proceedings of the $22^{\text {nd }}$ International Conference on Intelligent User Interfaces; March 13-16, 2017, Limassol, Cyprus. $22^{\text {nd }}$ International Conference. Limassol, Cyprus. IUI; International Conference on Intelligent User Interfaces. New York, New York: ACM Press, 343-355. http://dx.doi.org/10.1145/3025171.3025191 Accessed 28.12.2017.

O'REILLY, T., 2005. What Is Web 2.0: Design Patterns and Business Models for the Next Generation of Software. http://www.oreilly.com/ $\mathrm{pub} / \mathrm{a} /$ /web2/archive/what-is-web-20.html Accessed 11.12.2017. 
PAPMEHL-DUFAY, L., SÖDERSTRÖM, U., 2017. Creating Ambassadors Through Digital Media: Reflections from the Sandby Borg Project. Internet Archaeology 18(46), 60. http://dx.doi.org/10.11141/ ia.46.3 Accessed 28.12.2017.

PATRIKARAKOS, D., 2017. War in 140 Characters: How Social Media is Reshaping Conflict in the Twenty-first Century. New York: Basic Books.

PERRY, S., BEALE, N., 2015. The Social Web and Archaeology's Restructuring: Impact, Exploitation, Disciplinary Change. Open Archaeology 1(1), 153-165. http://dx.doi.org/10.1515/opar-2015-0009 Accessed 11.12.2017.

PILAAR BIRCH, S., 2013. Using Social Media for Research Dissemination: The Digital Research Video Project. Internet Archaeology 24(35), 145. http://dx.doi.org/10.11141/ia.35.4 Accessed 28.12.2017.

PINFIELD, S., SALTER, J., BATH, P.A., HUBBARD, B., MILlingtON, P., ANDERS, J.H.S., HUSSAIN, A., 2014. OpenAccess Repositories Worldwide, 2005-2012: Past Growth, Current Characteristics, and Future Possibilities. Journal of the Association for Information Science and Technology 65(12), 2404-2421. http://dx.doi. org/10.1002/asi.23131 Accessed 28.12.2017.

PODHOVNIK, E., 2016. The Meow Factor: An Investigation of Cat Content in Today's Media. In: J. Rotschedl, K. Cermakova, eds. Proceedings of the $1^{\text {st }}$ Arts \& Humanities Conference, Venice. Prague: International Institute of Social and Economic Sciences, 127-139. http:// dx.doi.org/10.20472/AHC.2016.001.013 Accessed 17.12.2017.

PUGIN, L., 2015. The Challenge of Data in Digital Musicology. Frontiers in Digital Humanities 2, 270. http://dx.doi.org/10.3389/fdigh.2015.00004 Accessed 28.12.2017.

REICHE, R., BECKER, R., BENDER, M., MUNSON, M., SCHMUNK, S., SCHÖCH, C., 2014. Verfahren der Digital Humanities in den Geistes- und Kulturwissenschaften. DARIAH-DE working papers 4. http://resolver.sub.uni-goettingen.de/purl/?dariah-2014-2 Accessed 16.12.2017.

REILLY, P., 1990. Towards a Virtual Archaeology. In: S. Rahtz, K. Lockyear, eds. CAA90: Computer Applications and Quantitative Methods in Archaeology. Oxford: Tempus Reparatum 133-139. http:// proceedings.caaconference.org/files/1990/21_Reilly_CAA_1990.pdf Accessed 16.12.2017.

RHEINGOLD, H., 1993. The Virtual Community: Homesteading on the Electronic Frontier. Reading: Addison-Wesley Publishing.

RICHARDSON, L.-J., 2012. Twitter \& Archaeology: An Archaeological Network in 140 Characters or Less. In: C. Bonacchi, ed. Archaeology and Digital Communication: Towards Strategies of Public Engagement. London: Archetype Publishing, 15-24.

RICHARDSON, L.-J., 2014. Public Archaeology in a Digital Age. Unpublished thesis (PhD). University of London. http://discovery.ucl. ac.uk/1436367/ Accessed 21.12.2017.

RICHARDSON, L.-J., 2015. Micro-blogging and Online Community. Internet Archaeology (39). http://dx.doi.org/10.11141/ia.39.2 Accessed 28.12.2017.

RICHARDSON, L.-J., 2017. I'll Give you "Punk Archaeology", Sunshine. World Archaeology 49(3), 306-317. http://dx.doi.org/10.1080/00438243. 2017.1333036 Accessed 28.12.2017.

RICHARDSON, L.-J., ALMANSA-SÁNCHEZ, J., 2015. Do You Even Know What Public Archaeology Is?: Trends, Theory, Practice, Ethics. World Archaeology 47(2), 194-211. http://dx.doi.org/10.1080/00438243. 2015.1017599 Accessed 11.12.2017.

RICHARDSON, L.-J., DIXON, J., 2017. Public Archaeology 2015: Letting Public Engagement with Archaeology “Speak for Itself”. Internet Archaeology 46, 132. http://dx.doi.org/10.11141/ia.46.7 Accessed 28.12.2017.

ROCKS-MACQUEEN, D., 2016. Digital Public Engagement through Social Media in Archaeology - How to Choose. Present Pasts 7(1). http:// dx.doi.org/10.5334/pp.62 Accessed 28.12.2017.

Roman Rural Landscapes 2017. http://rrl.univie.ac.at/ Accessed 21.12.2017. RÖHLE, B.R.T., 2012. Digital Methods: Five Challenges. In: D. M. Berry, ed. Understanding Digital Humanities. Houndmills, New York: Palgrave Macmillan, 67-84. http://dx.doi.org/10.1057/9780230371934_4 Accessed 05.03.2018.

ROSEN, A., 2017. Tweeting Made Easier. https://blog.twitter.com/ official/en_us/topics/product/2017/tweetingmadeeasier.html Accessed 12.12.2017.
SCHOFIELD, J., 2017. "Deviants, Punks and Pink Fairies": Counterarchaeologies for Unreasonable People. World Archaeology 49(3), 281-290. http://dx.doi.org/10.1080/00438243.2017.1383182 Accessed 28.12.2017.

SCHOLZ, H., 2017. Social Networks: Funktionen, Marktstellung, Nutzung. In: H. Scholz, ed. Social goes Mobile - Kunden gezielt erreichen: Mobile Marketing in Sozialen Netzwerken. $2^{\text {nd }}$ ed. Wiesbaden: Springer, 3-15. https://doi.org/10.1007/978-3-658-16604-5_1 Accessed 17.12.2017.

SCHÖRNER, G., HAGMANN, D., 2015. Intensiver archäologischer Survey im nördlichen Etrurien. Forum Archaeologiae 76(9). http:// dx.doi.org/10.17613/M6V83S Accessed 23.12.2017.

SCHUBERT, C., 2015. Close Reading und Distant Reading: Methoden der Altertumswissenschaften in der Gegenwart. Digital Classics Online 1(1). http://dx.doi.org/10.11588/dco.2015.1.20483 Accessed 28.12.2017.

SEDLACIK, M.T., 2015. Social Media and Heritage Preservation. Present Pasts 6(1). http://dx.doi.org/10.5334/pp.60 Accessed 14.12.2017.

SHELDON, P., BRYANT, K., 2016. Instagram: Motives for Its Use and Relationship to Narcissism and Contextual Age. Computers in Human Behavior 58, 89-97. http://dx.doi.org/10.1016/j.chb.2015.12.059 Accessed 22.12.2017.

SHUAI, X., PEPE, A., BOLlEN, J., 2012. How the Scientific Community Reacts to Newly Submitted Preprints: Article Downloads, Twitter Mentions, and Citations. PloS one 7(11), e47523. http://dx.doi. org/10.1371/journal.pone.0047523 Accessed 29.12.2017.

SIART, C., FORBRIGER, M., BUBENZER, O., 2017. Digital Geoarchaeology: Bridging the Gap Between Archaeology, Geosciences and Computer Sciences. In: C. Siart, M. Forbriger, O. Bubenzer, eds.: Digital Geoarchaeology: New Techniques for Interdisciplinary Human-environmental Research. Cham: Springer, 1-9. https://doi. org/10.1007/978-3-319-25316-9_1 Accessed 11.12.2017.

SINCLAIR, A., 2016. The Intellectual Base of Archaeological Research 2004-2013: A Visualisation and Analysis of its Disciplinary Links, Networks of Authors and Conceptual Language. Internet Archaeology 42. http://dx.doi.org/10.11141/ia.42.8 Accessed 28.12.2017.

Sketchfab, 2017. https://sketchfab.com/ Accessed 21.12.2017.

SMALL, T.A., 2011. What The Hashtag?: A Content Analysis of Canadian Politics on Twitter. Information, Communication \& Society 14 (6), 872-895. http://dx.doi.org/10.1080/1369118X.2011.554572 Accessed 14.12.2017.

SMITH, M.E., FEINMAN, G.M., DRENNAN, R.D., EARLE, T., MORRIS, I., 2012. Archaeology as a Social Science. Proceedings of the National Academy of Sciences of the United States of America 109(20), 7617-7621. http://dx.doi.org/10.1073/pnas.1201714109 Accessed 28.12.2017.

SOLIMAN, A., SOLTANI, K., YIN, J., PADMANABHAN, A., WANG, S., 2017. Social Sensing of Urban Land Use Based on Analysis of Twitter Users' Mobility Patterns. PloS one 12(7), e0181657. http://dx.doi. org/10.1371/journal.pone.0181657 Accessed 28.12.2017.

SOLODOVNIK, I., BUDRONI, P., 2015. Preserving Digital Heritage: At the Crossroads of Trust and Linked Open Data. International Federation of Library Associations and Institutions 41(3), 251-264. http://dx.doi. org/10.1177/0340035215600453 Accessed 22.12.2017.

STEPHENS, K.K., 2007. The Successive Use of Information and Communication Technologies at Work. Communication Theory 17(4), 486-507. http://dx.doi.org/10.1111/j.1468-2885.2007.00308.x Accessed 16.12.2017.

SUTTER, J.D., 2012. Will Twitter War Become the New Norm? (Cable News Network). http://edition.cnn.com/2012/11/15/tech/social-media/ twitter-war-gaza-israel/index.html Accessed 12.12.2017.

THALLER, M., 2017a. Digital Humanities als Wissenschaft. In: F. Jannidis, H. Kohle, M. Rehbein. eds. Digital Humanities. Stuttgart: J.B. Metzler, 13-18. http://dx.doi.org/10.1007/978-3-476-05446-3_2 Accessed 16.12.2017.

THALLER, M., 2017b. Geschichte der Digital Humanities. In: F. Jannidis, H. Kohle, M. Rehbein eds. Digital Humanities. Stuttgart: J.B. Metzler., 3-12. https://doi.org/10.1007/978-3-476-05446-3_1 Accessed 16.12.2017.

THELWALL, M., KOUSHA, K., 2014. Academia.edu: Social network or Academic Network? Journal of the Association for Information Science and Technology 65 (4), 721-731. http://dx.doi.org/10.1002/asi.23038 Accessed 28.12.2017. 
THELWALL, M., KOUSHA, K., 2015. ResearchGate: Disseminating, Communicating, and Measuring Scholarship? Journal of the Association for Information Science and Technology 66(5), 876-889. http://dx.doi. org/10.1002/asi.23236 Accessed 14.12.2017.

THELWALL, M., KOUSHA, K., 2017. ResearchGate Articles: Age, Discipline, Audience Size, and Impact. Journal of the Association for Information Science and Technology 68(2), 468-479. http://dx.doi. org/10.1002/asi.23675 Accessed 28.12.2017.

TROGNITZ, M., HAGMANN, D., RÄTHER, J., JAHN, S., 2017. Datenmanagement. In: IANUS - Forschungsdatenzentrum für Archäologie \& Altertumswissenschaften, M. Heinrich, F. Schäfer, M. Trognitz, eds. IT-Empfehlungen für den nachhaltigen Umgang mit digitalen Daten in den Altertumswissenschaften: Version 1.0.0.0, 29.03.2017. IANUS - FDZ Archäologie \& Altertumswissenschaften, 16-26. http://dx.doi.org/10.13149/000.y47clt-t Accessed 17.12.2017.

Twitter, 2017a. About Replies and Mentions. https://help.twitter.com/en/ using-twitter/mentions-and-replies Accessed 11.12.2017.

Twitter, 2017b. How to Retweet. https://help.twitter.com/en/using-twitter/ how-to-retweet Accessed 11.12.2017.

Twitter, 2017c. How to Use Hashtags. https://help.twitter.com/en/usingtwitter/how-to-use-hashtags Accessed 11.12.2017.

Twitter, 2017d. Search query "twitterwar". https://witter.com/ search?src=typd\&q=twitterwar Accessed 12.12.2017.

Twitter. Activity dashboard, 2017e. https://business.twitter.com/en/ analytics/tweet-activity-dashboard.html Accessed 21.12.2017.

Twitter. Ads campaigns, 2017f. https://business.twitter.com/en/twitter-ads. html Accessed 22.12.2017.

Twitter Analytics, 2017. https://analytics.twitter.com/ Accessed 21.12.2017.

VAN DEN DRIES, M.H., 2014. Community Archaeology in the Netherlands. Journal of Community Archaeology \& Heritage 1(1), 69-88. http://dx.doi.org/10.1179/2051819613Z.0000000008 Accessed 28.12.2017.

VAN NIEKERK, B., MAHARAJ, M., 2013. Social Media and Information Conflict. International Journal of Communication 7, 1162-1184. http:// ijoc.org/index.php/ijoc/article/view/1658/0 Accessed 12.12.2017.

VERHAGEN, P., 2017. Spatial Analysis in Archaeology: Moving into New Territories. In: C. Siart, M. Forbriger, O. Bubenzer, eds. Digital Geoarchaeology: New Techniques for Interdisciplinary Humanenvironmental Research. Cham: Springer, 11-25. http://dx.doi. org/10.1007/978-3-319-25316-9_2 Accessed 28.12.2017.

VOBIČ, I., MAKSUTI, A., DEŽELAN, T., 2016. Who Leads the Twitter Tango?: Studying the Journalist-politician Relationship in Slovenia Through Twitter Conversations. Digital Journalism 5(9), 1134-1154. http://dx.doi.org/10.1080/21670811.2016.1259002 Accessed 28.12.2017.

WADHWA, V., LATIMER, E., CHATTERJEE, K., MCCARTY, J., FITZGERALD, R.T., 2017. Maximizing the Tweet Engagement Rate in Academia: Analysis of the AJNR Twitter Feed. American Journal of Neuroradiology 38(10), 1866-1868. http://dx.doi.org/10.3174/ajnr. A5283.
WALKER, D., 2014. Antisocial Media in Archaeology? Archaeological Dialogues 21(02), 217-235. http://dx.doi.org/10.1017/ S1380203814000221 Accessed 28.12.2017.

WARWICK, C., TERRAS, M.M., NYHAN, J., 2012. Digital Humanities in Practice, London: Facet Publishing.

WATKINS, J.E., 2016. Communicating Archaeology. Journal of Social Archaeology6(1),100-118.http://dx.doi.org/10.1177/1469605306060569 Accessed 22.12.2017.

WILliAMS, H., ATKIN, A., 2015. Virtually Dead: Digital Public Mortuary Archaeology. Internet Archaeology 37(40), 23. http://dx.doi. org/10.11141/ia.40.7.4 Accessed 28.12.2017.

WILLIAMS, L.Y., KRAUSE J., 2012. Pragmatics of Twitter Use for Academics: Tweeting in and out of the Classroom. In: D. R. Neal, ed. Social Media for Academics: A Practical Guide. Oxford: Chandos Publishing, 105-122.

WOLF, J.M., 2017. The Multipurpose Tool of Social Media: Applications for Scientists, Science Communicators, and Educators. Clinical Microbiology Newsletter 39(10), 75-79. http://dx.doi.org/10.1016/j. clinmicnews.2017.04.003 Accessed 28.12.2017.

WOOLSTON, C., 2015. Word-processing War Flares Up on Social Media. Nature 517(7533), 125. http://dx.doi.org/10.1038/517125f Accessed 11.12.2017.

WORKEWYCH, A.M., CIUFFETELLI MUZZI, M., JING, R., ZHANG, S., TOPOLOVEC-VRANIC, J., CUSIMANO, M.D., 2017. Twitter and traumatic brain injury: A content and sentiment analysis of tweets pertaining to sport-related brain injury. SAGE open medicine 5, 2050312117720057. http://dx.doi.org/10.1177/2050312117720057 Accessed 28.12.2017

XIA, J., 2012. Open Access for Archaeological Literature: A Manager's Perspective. In: E.C. Kansa, S.W. Kansa, E. Watrall, eds. Archaeology 2.0: New Tools for Communication and Collaboration. Los Angeles, Oxford: Oxbow 233-249.

YU, M.-C., WU, Y.-C.J., ALHALABI, W., KAO, H.-Y., WU, W.H., 2016. ResearchGate: An Effective Altmetric Indicator for Active Researchers? Computers in Human Behavior 55, 1001-1006. http:// dx.doi.org/10.1016/j.chb.2015.11.007 Accessed 28.12.2017.

ZHU, Y., PURDAM, K., 2017. Social Media, Science Communication and the Academic Super User in the United Kingdom. First Monday 22(11). http://dx.doi.org/10.5210/fm.v22i11.7866 Accessed 28.12.2017.

ZUANNI, C., 2017. Unintended Collaborations: Interpreting Archaeology on Social Media. Internet Archaeology 17(46), 101. http://dx.doi. org/10.11141/ia.46.2 Accessed 28.12.2017.

ZUBROW, E.B.W., 2006. Digital Archaeology: A Historical Context. In: T.L. Evans, P.T. Daly eds. Digital archaeology: Bridging Method and Theory. London, New York: Routledge, 10-32.

ZUPPO, C.M., 2012. Defining ICT in a Boundaryless World: The Development of a Working Hierarchy. International Journal of Managing Information Technology 4(3), 13-22. http://dx.doi.org/10.5121/ ijmit.2012.4302 Accessed 28.12.2017. 